\title{
Fotografia, arquitetura, arte e propaganda: a Brasília de Marcel Gautherot em revistas, feiras e exposições?
}

\begin{abstract}
Heloisa Espada ${ }^{2}$
RESUMO: Entre o fim dos anos 1950 e o início dos 1960, o fotógrafo francês Marcel Gautherot (1910 - 1996) viajou diversas vezes à Brasília para registrar o canteiro de obras e a recém inaugurada arquitetura da nova capital. Comissionado por Oscar Niemeyer (1907-2012), pela Novacap (Companhia Urbanizadora da Nova Capital) e por empresas particulares, produziu um dos mais importantes testemunhos visuais sobre o assunto, tendo suas fotos amplamente divulgadas em revistas e exposições de arquitetura, no Brasil e no exterior. Este texło aborda a veiculação das imagens de Gautherot nesses diferentes contextos, no período em que foram produzidas. Analisa os sentidos adquiridos por suas fotos em projetos gráficos modernos, bem como sua participação em planos museográficos altamente sofisticados. Por outro lado, Gautherot esteve atento também aos bolsões de pobreza que se instalaram nos arredores do Plano Piloto de Brasília. No entanto, nos anos 1950 e 1960, ele não encontrou veículos de comunicação interessados na divulgação dessas imagens.

PALAVRAS-CHAVE: Marcel Gautherot. Brasilia. Fotografia. Fotografia moderna. Divulgação. Sacolândia.

ABSTRACT: Between the end of 1950's and the earlier 1960's, the French photographer Marcel Gautherot (1910 - 1996) traveled several times to Brasilia in order to register the city under construction and the architeture of the new capital. Contracted by Oscar Niemeyer (1907-20 12 ), by Novacap (Government Urbanization Company of the New Capital) and by commercial companies, he produced one of the most important visual testemonies about the subject. His images were largely published in magazines and exhibitions in Brazil and foreign countries. This article analyses the divulgation of Gautherot's pictures in these contexts, during the time that they were taken. It analyses the senses of his photos when part of modern graphic design projects and very sophisticated exhibitions. On the other hand, Gautherot was aware of and took pictures of the areas of poverty around the Pilot Plan of Brasilia. However, in the 1950's and 1960's, he didn't find medias interested in publishing these images.

KEYWORDS: Marcel Gautherot. Brasilia. Photography. Modern architecture. Divulgation. Sacolândia.
\end{abstract}

1. Este artigo apresenta alguns resultados da tese $M o$ numentalidade e sombra: a representação do centro cívico de Brasília por Marcel Gautherot, defendida em 2011 junto ao Programa de Pós-Graduação em Artes Visuais da ECA/USP.

2. Doutora em Artes pela Escola de Comunicações e Artes da Universidade de São Paulo (ECA/USP); coordenadora do Departamento de Artes Visuais do Instituto Moreira Salles (IMS). E-mail: <heloisa.espada@ gmail.com>. 
3. Ver Walter Benjamin (1994 [1931], p. 117).

4. As fotos integram o acervo do Instituto Moreira Salles que, em 1999, adquiriu a coleção de aproximadamente 25 mil imagens realizadas por Marcel Gautherot ao longo de sua trajetória profissional.

5. As informações sobre as empresas para as quais Gautherot prestou serviços foram tiradas dos depoimentos de Oscar Niemeyer, Alcides Rocha Miranda, Janine e Olivier Gautherot (esposa e filho do fotógrafo), Augusto da Silva Telles e Marcos Jaimovich a Ana Luiza Nobre, em 2001 e 2002. As entrevistas integram o acervo do Instituto Moreira Salles.
Preâmbulo

No final de sua Pequena história da fotografia, de 1931, Walter Benjamin afirma que sem uma legenda "qualquer construção fotográfica corre o risco de permanecer vaga e aproximativa", para em seguida lançar a provocação: "Não se tornará a legenda a parte mais essencial da fotografia?" 3 . Para o autor, a função do texto seria a de conferir literalidade a esse tipo de imagem, resguardando o observador de sua natureza imprecisa, ou seja, das diferentes possibilidades de interpretação oferecidas por uma foto. A condição "vaga" apontada por Benjamin faz com que uma imagem fotográfica seja extremamente porosa aos diferentes tipos de "legendas" - mesmo as não literais - que a acompanham: as circunstâncias de sua apresentação, seu tamanho, o tipo de papel ou a diagramação de uma página.

objetivo deste texto é apresentar as fotografias de Brasília feitas por Marcel Gautherot no contexto original em que foram divulgadas: revistas, feiras e exposições de circulação nacional e internacional.

Entre o fim dos anos 1950 e o início dos 1960, ele viajou diversas vezes a Brasília para registrar a construção e os primeiros anos da cidade, produzindo cerca de 3500 negativos sobre o assunto ${ }^{4}$. Gautherot fotografou o aeroporto, o palácio da Alvorada, o Brasília Palace Hotel, o Catetinho e diversas vistas aéreas mostrando o início das obras do eixo monumental. $\bigcirc$ Congresso Nacional, a Esplanada dos Ministérios, a Catedral Metropolitana Nossa Senhora Aparecida, a praça dos Três Poderes, o Palácio do Planalto, o Supremo Tribunal Federal, o Teatro Nacional Cláudio Santoro e a Universidade de Brasília foram registrados durante a construção e depois de prontos. Produziu uma longa série sobre o canteiro de obras e outra menor, com cerca de 70 imagens, sobre os acampamentos conhecidos como Sacolândia, onde famílias de operários viviam em barracos feitos com sacos de cimento vazio. Há alguns poucos registros da festa de inauguração e séries sobre as superquadras, o palácio do Itamaraty e o Palácio da Justiça. Além do que podemos classificar claramente como "fotografias de arquitetura", o conjunto possui uma série de "digressões fotográficas", autorretratos e imagens de índole lírica, feitas sem a preocupação de uma aplicação prática.

Fotografou Brasília a pedido de Oscar Niemeyer. Foi comissionado pelo próprio arquiteto e pela Novacap, a Companhia Urbanizadora da Nova Capital, de cujo Departamento de Urbanismo e Arquitetura Niemeyer foi diretor. Também fotografou a capital para agências de publicidade francesas, empresas como a Air France e Aerospatiale. Na capital, seguiu o modelo de trabalho free-lance adotado desde que se radicou no Brasil, em 1940, quando passou a colaborar com regularidade para o Serviço do Patrimônio Histórico e Artístico Nacional; para a Comissão Nacional de Folclore, criada em 1947; para a Campanha de Defesa do Folclore Brasileiro, a partir de 1958; para empresas particulares, como a Companhia de Seguros Sul América; ; além de ter se tornado um dos principais fotógrafos da emergente arquitetura moderna brasileira. Ele muitas vezes viajava por conta própria para depois vender suas fotos para órgãos públicos, empresas e arquitetos. 
Como demonstraram Heliana Angotti-Salgueiro e Lygia Segala na extensa pesquisa que deu origem à exposição e ao livro-catálogo $\bigcirc$ olho fotográfico: Marcel Gautherot e seu tempo, a formação do artista - do ponto de vista conceitual, estético e técnico - se deu em Paris, no período entreguerras. Na capital francesa, ele estudou arquitetura e decoração de interiores na Escola Nacional Superior de Artes Decorativas, entre 1925 e 1927, tendo abandonado o curso no último ano para trabalhar como designer na fábrica de móveis Gustave Moeder, em Estrasburgo. Ali, Gautherot desenhou móveis modernos, geométricos e sem adornos e, nos anos 1920 e 1930, visitou diversas exposições de arquitetura moderna e de decoração de interiores $^{6}$. Nesses eventos, entrou em contato com as propostas da Deutsche Werkbund (Liga Alemã de Trabalho)?, conheceu trabalhos de arquitetos como Mies Van der Rohe, Walter Gropius e Le Corbusier, tendo se interessado particularmente pelas propostas deste último.

A partir do pós-guerra, os registros da arquitetura brasileira feitos por Gautherot tiveram uma ampla circulação internacional. Além das colaborações constantes estabelecidas com Niemeyer e Roberto Burle Marx, ele fotografou obras de Affonso Eduardo Reidy, Lucio Costa, Alcides da Rocha Miranda, Paulo Antunes Ribeiro e dos irmãos Marcelo, Milton e Maurício Roberto. A pesquisadora Ana Luiza Nobre - uma das primeiras estudiosas a se dedicar à análise das fotos de arquitetura de Gautherot - considera que a qualidade plástica de suas imagens contribuiu decisivamente para a divulgação e para a valorização da arquitetura moderna brasileira, "a ponto de ser difícil pensá-la sem recorrer às imagens de Gautherot" 8 .

Sobre relações entre fotografia e arquitetura moderna

Desde o anúncio oficial da invenção da fotografia, em 1839, a arquitetura foi um dos principais temas do novo aparato. Além da ampla circulação alcançada por imagens de arquitetura de caráter turístico por meio de periódicos, álbuns e postais, ao longo do século XIX, as fotografias documentaram grandes reformas urbanísticas realizadas em cidades como Paris, registrando também as ruas e as construções que desapareceram com as mudanças.

A circulação de imagens arquitetônicas rapidamente se beneficiou dos melhoramentos técnicos dos métodos de impressão. Desde o fim dos anos 1880, a invenção da impressão de meio-tom permitiu que fotografias fossem reproduzidas junto a textos numa mesma página, o que impulsionou o surgimento de novas revistas ilustradas. Imediatamente, em todo o mundo foram criadas numerosas publicações de arquitetura, tais como a norte-americana Architectural Record (1897) e as britânicas Architectural Review (1 896) e Country Life (1897). No fim da primeira década do século XX, a maior parte dessas revistas já usava o meiotom, embora a qualidade de impressão ainda fosse muito instável. Até esse período, os registros de arquitetura obedeciam sobretudo a uma retórica da impessoalidade: os enquadramentos quase sempre mostravam o edifício inteiro e iluminado de forma
6. Ver Heliana Angotti-Salgueiro (2007, p. 69-71).

7. Associação criada na Alemanha, em 1907, com o objetivo de reunir artistas, industriais, artesãos e comerciantes a fim de promover uma produção industrial de alta qualidade. Sua primeira exposição, em Colônia, em 1914, lançou Walter Gropius e Adolf Meyer, então jovens arquitetos. A Werkbund é uma das origens da Bauhaus.

8. Cf. Ana Luiza Nobre (2001b, p. 22). 
9. Le Corbusier utilizou amplamente imagens fotográficas para construir seus argumentos. Isso é visível, por exemplo, em seus textos publicados na revista L'Esprit Nouveau e em seus livros Vers une architecture (1998) e Urbanism (2009).

10. Ver Robert Elwal (2004, p. 125). homogênea; as imagens eram publicadas sem crédito, adaptadas a padrões editoriais e layouts sobre os quais o fotógrafo não tinha controle.

Sendo ao mesmo tempo publicidade e fonte de informação, a fotografia de arquitetura exerceu um papel central no processo de difusão e legitimação das obras e ideias modernas? ${ }^{9}$. No entreguerras, a expansão das revistas ilustradas somada aos avanços no campo da óptica e do design das câmeras, mais leves e mais ágeis, estimulou também a demanda pelos registros de arquitetura que, como a fotografia de imprensa de modo geral, assimilou as experimentações formais das vanguardas, especialmente do construtivismo, do cubismo e da Nova Visão. É no entreguerras, portanto, que os fotógrafos passam a explorar as qualidades abstratas da arquitetura moderna, fazendo com que muitas vezes um detalhe pudesse representar um edifício. Paul Strand e Lazsló Moholy-Nagy, por exemplo, estão entre os artistas que trabalharam com a arquitetura como assunto para a experimentação fotográfica.

Conforme Elwall, a fotografia moderna influenciou também a crítica e, de maneira decisiva, a percepção do público em geral sobre a arquitetura funcionalista ${ }^{10}$. No pós-guerra, aumenta ainda mais o número de revistas de arquitetura, bem como o destaque conferido à fotografia na diagramação. Os periódicos competem pela divulgação de edifícios inéditos e, por isso, muitos passam a ser mostrados em construção. A fotografia criou muitas vezes uma visão icônica do edifício, o que pode ser dito, por exemplo, de algumas fotos de Gautherot sobre os palácios de Brasília.

Os arquitetos modernos logo se deram conta do poder de persuasão da imagem fotográfica, de sua capacidade de interpretar um projeto e de determinar como uma obra seria vista. Muitos deles passaram a interferir e a acompanhar o trabalho dos fotógrafos. Em 1922, Edmund Lill documentou a fábrica Fagus, na Alemanha, projeto de Walter Gropius e Adolf Meyer, sob supervisão desse último. Além disso, editores da Architectural Review, outro exemplo, frequentemente acompanhavam os fotógrafos com o intuito de indicar pontos de vista e as melhores condições de luz. Algumas parcerias entre arquitetos e fotógrafos se tornaram célebres, como as de Richard Neutra e Julius Schulmann, Le Corbusier e Lucien Hervè, Mies van der Rohe e Richard Meyer, Oscar Niemeyer e Marcel Gautherot.

Outra importante forma de divulgação da arquitetura ao longo dos séculos XIX e XX foram as feiras e exposições universais, com grande destaque para os pavilhões construídos especialmente para os eventos, dentro dos quais a apresentação de obras arquitetônicas era feita, sobretudo, por meio de fotografias. De motivação econômica e política, as grandes exposições funcionavam como um estímulo à indústria e ao comércio internacional, sendo uma vitrine para novas tecnologias, riquezas naturais e bens de consumo. A Grande Exposição Industrial de Todas as Nações, ocorrida em Londres, em 1851, ocupou uma área de $105.200 \mathrm{~m}^{2}$, contou com 14.000 expositores e seis milhões de visitantes. A ocasião evidenciou o papel das exposições como um meio de publicidade para 
o novo sistema econômico baseado na produção industrial. Outro exemplo paradigmático é a Feira Universal de Paris, de 1900, com 83.000 expositores e um público de 39 milhões de pessoas. A arquitetura aparecia como representante da identidade de um país, como demonstração de sua competência artística, industrial e tecnológica. De meados do século XIX até aproximadamente a década de 1960, as grandes feiras internacionais receberam multidões, exercendo uma grande influência sobre o público e a economia internacional ${ }^{11}$.

Um marco entre as exposições de arquitetura propriamente ditas foi a mostra 20 anos de arquitetura britânica, em 1923, na Royal Academy de Londres, composta, sobretudo, por registros fotográficos. $\bigcirc$ evento é considerado como a primeira mostra de arquitetura a atrair um grande público ${ }^{12}$. Outro exemplo marcante é a exposição The International Style, realizada em 1932 pelo Museu de Arte Moderna de Nova York, sob curadoria de Henry-Russel Hitchcock e Philip Johnson, composta por maquetes e grandes painéis fotográficos com projetos de Alvar Aalto, Walter Gropius, Le Corbusier, Mies van der Rohe e Richard Neutra, entre outros.

Os movimentos artísticos modernos influenciaram diretamente a estética das exposições. Até a última década do século XIX, predominou o historicismo arquitetônico ensinado nas Escolas de Belas-Artes. Nas primeiras décadas do século XX, o Art Nouveau ganhou força sobretudo no âmbito da decoração de interiores, bem como as propostas da Deutsche Werkbund, que em 1914, em Colônia, apresentou projetos de Van de Velde e Walter Gropius, apontando claramente os rumos da nova arquitetura europeia. Durante a Primeira Guerra Mundial, o cubismo - com sua ênfase na geometria -, o movimento holandês De Stijl, a Bauhaus e o construtivismo - com seus sentidos de economia formal, serialização e padronização - interferiram decisivamente no design de exposições. Duas mostras foram centrais nesse processo: a Exposição de artes decorativas de Paris, em 1925, onde Le Corbusier apresentou seu pavilhão L'Esprit Nouveau, e a mostra alemã da Werkbund, em Stuttgart, 1927, visitada por Marcel Gautherot ${ }^{13}$.

Em 1930, o governo alemão confiou a Walter Gropius, Herbert Bayer, Marcel Brever e László Moholy-Nagy o projeto da seção alemã da Exposição de Artes Decorativas de Paris. A mostra apresentou um panorama das realizações da Alemanha nos campos da arquitetura, da decoração de interiores, do design de utensílios e das artes aplicadas. No interior da exposição, a fotografia foi incorporada ao projeto expográfico na forma de grandes painéis murais, como no exemplo da sala 5 projetada por Herbert Bayer, com a maquete e imagens da Bauhaus de Dessau junto de cadeiras desenhadas por Marcel Breuer e Mies van der Rohe.

Em 1931, em Berlim, Gropius, Moholy-Nagy e Herbert Bayer trabalharam juntos novamente no projeto da exposição da união de construtores civis alemães, cujo objetivo era apresentar estatísticas e tendências do setor. grupo utilizou novamente grandes painéis combinando fotografia e artes gráficas.
11. Ver Richard Paul Lohse (1953, p. 12-13).

12. Ver Robert Elwall (2004, p. 125).

13. Ver Heliana Angotti-Salgueiro (2007, p. 71). 
14. Ver Lauro Cavalcanti (2006, p. 184).

15. Após Brazil Builds, Kidder Smith realizou três livros similares: Sweden builds (1950), Switzerland builds (1950) e Italy builds (1955), sobre a arquitetura histórica e contemporânea desses países.

16. Outros fotógrafos e estúdios, citados por Philip Goodwin, que contribuíram para a publicação foram: Erich Hess, Carlos, Photo Rembrandt, Photo Stille, Benicio Whatley Dias, Burton Holmes, Samuel Gottscho. Além disso, a Biblioteca Pública de Nova York, as revistas The Architectural Record, The Architectural Forum e Acrópole forneceram imagens para o livro.

17. Além de Marcel Gautherot, participaram do livro os fotógrafos Francisco Albuquerque, Hans Gunther Flieg, Voltaire Fraga, Jean Manzon, José Medeiros, Flávio Damm, Peter Scheier e a loja Fotoptica, da família Farkas.
Arquitetura brasileira em circulação

No Brasil, a divulgação da arquitetura moderna aconteceu, como nos países europeus e na América do Norte, por meio de publicações especializadas, das feiras internacionais, que visavam a difusão cultural e o aquecimento do comércio exterior, e de exposições de arquitetura, muitas vezes de caráter oficial. Além do destaque alcançado pelos próprios projetos arquitetônicos dos pavilhões brasileiros em feiras internacionais, a apresentação dos produtos, dos recursos naturais, de manifestações populares e da arquitetura brasileira se deu por meio de fotografias.

Um exemplo bastante conhecido é o pavilhão do Brasil, projeto de Lucio Costa e Niemeyer, na Feira Mundial de Nova York, em 1939 e 1940, evento que foi um grande palco de difusão das culturas nacionais ali presentes. Marcel Gautherot participou com fotos de Ouro Preto, de obras de Aleijadinho, do edifício da Associação Brasileira de Imprensa e do Ministério da Educação e da Saúde Pública ${ }^{14}$.

Após o sucesso do pavilhão do Brasil, o acontecimento que mais despertou o interesse internacional para as construções brasileiras foi a exposição Brazil Builds: Architecture New and Old, 1652-1942, realizada pelo Museu de Arte Moderna de Nova York, em 1943 e 1944. Outra mostra importante foi Latin American Archifecture since 1945, organizada também no MoMA, em 1955, pelo curador Henry-Russel Hitchcock e a fotógrafa Rosalie Thorne McKenna. Mas foi sobretudo após Brazil Builds que revistas internacionais de peso passaram a dar atenção especial à produção brasileira. Architectural Record, em 1944, e L'Architecture d'Aujourd'hui e Architectural Forum, em 1947, editaram números especiais sobre a arquitetura do país.

Durante 1942, o arquiteto Philip Goodwin, curador de Brazil Builds, e George Kidder Smith, considerado um dos principais fotógrafos de arquitetura dos Estados Unidos, passaram cerca de seis meses no Brasil colhendo informações e imagens para a exposição. A mostra, composta principalmente por fołografias, e o livro homônimo que a acompanhou traçavam relações estéticas entre a arquitetura colonial e moderna do Brasil, de forma semelhante à interpretação histórica já proposta por Lucio Costa. A maior parte das imagens do livro Brazil Builds é de Kidder Smith'15, mas há também fotos de Gautherot realizadas no Rio de Janeiro, entre outros profissionais ${ }^{16}$.

Nota-se que a fotografia tem um papel central nos dois livros mais importantes sobre arquitetura brasileira surgidos nos anos 1940 e 1950: Brazil Builds e Modern Architecture in Brazil, de Henrique Mindlin, lançado em 1956. Gautherot é o fotógrafo com maior participação nessa segunda publicaçãa ${ }^{17}$, uma espécie de catálogo com fotos, plantas e descrições de obras modernas construídas no Brasil, que se tornou uma referência internacional sobre o assunto. No prefácio da publicação, o crítico suíço Siegfried Giedion chama a atenção para a capacidade dos brasileiros de evitar a rigidez formal como a principal característica de sua produção. Em ambos os livros, o discurso fotográfico é de viés documental, sendo a imagem apresentada como um signo transparente, como uma janela de acesso às obras arquitetônicas. Os enquadramentos evitam fragmentações e, na 
grande maioria dos casos, obedecem o sentido ortogonal. Uma exceção é o recorte da igreja de São Francisco de Assis, em Salvador, uma composição diagonal criada pela rotação da câmera, que integra Brazil Builds ${ }^{18}$.

Gautherot e Niemeyer

A parceira entre Marcel Gautherot e Oscar Niemeyer foi iniciada nos anos 1940, quando o fotógrafo documentou as obras do arquiteto no bairro da Pampulha, em Belo Horizonte. $\bigcirc$ fotógrafo colaborou intensamente com publicações fundamentais para a difusão internacional da obra de Niemeyer, como as de autoria do arquiteto grego Stamo Papadaki, editadas nos Estados Unidos, Reino Unido, Itália e Japão ${ }^{19}$. Suas imagens do canteiro de obras e dos monumentos oficiais de Brasília quando prontos foram amplamente publicadas na Módulo: Revista de Arquitetura e Artes Plásticas, dirigida por Niemeyer e voltada principalmente para a divulgação de seus projetos. Em quantidade bem menor, apareceram também na revista Brasília, então editada pela Novacap ${ }^{20}$. Fora do Brasil, entre o final dos anos 1950 e a década de 1960, suas fotos ilustraram matérias de revistas, como as norte-americanas The Architectural Forum e Arts \& Architecture, as francesas Aujourd'hui Art et Architecture e L'Architecture d'Aujourd'hui. Além disso, desde a construção de Brasília, essas imagens continuaram sendo amplamente editadas em livros, manuais e revistas, nacionais e internacionais sobre Brasília, sobre arquitetura brasileira, sobre Oscar Niemeyer e, mais recentemente, sobre a própria obra de Marcel Gautherot. Nos últimos anos, elas ultrapassaram a fronteira da fotografia arquitetônica para figurar em mostras de artes visuais, algumas delas sobre a arte geométrica construtiva no Brasil ou na América Latina ${ }^{21}$.

É preciso lembrar que a fotografia de arquitetura é feita na maior parte das vezes para ser vista em sua forma de reprodução e não como uma obra única. No caso de Gautherot, a despeito de seu rigor e preciosismo técnico, podemos afirmar que ele não trabalhava com o conceito de fine art. Há em seu acervo, sob os cuidados do Instituto Moreira Salles, pouquíssimas imagens ampliadas por ele, e as que restaram não denotam uma preocupação em conferir à ampliação a aura de objeto único. Suas fotos pertencentes ao arquivo Noronha Santos, do IPHAN, outro exemplo, têm diferentes tamanhos, papéis e formatos que não seguem o enquadramento original da imagem.

Embora Niemeyer tenha usado amplamente fotografias de Gautherot em publicações sobre seu trabalho, e com frequência comente sua amizade e preferência pelas fotos do profissional22, não foram encontrados documentos comprovando que o arquiteto orientava o registro de suas obras. Em depoimento ao Programa de História Oral do Arquivo Histórico do Distrito Federal, o arquiteto Hermano Montenegroafirma que Gautherot, por conhecer bem Niemeyer e estar habituado a fotografar Brasília, "(...) sabia o ângulo, sabia o tipo de céu, essas coisas" que o autor dos projetos gostaria de ver ${ }^{23}$. Os dois conviveram e viajaram diversas vezes juntos - o que deve ter propiciado trocas de impressões e informações
18. Ver Philip Goodwin (1943, p. 63).

19. Ver Stamo Papadaki (1950).

20. O fotógrafo Mário Fontenelle foi o principal colaborador da revista Brasília.

21. Ver Robert Kudielka et al (2010) e Fundación Juan March (2011).

22. Ver Instituto Moreira Salles (2001, p. 7, Fundação Oscar Niemeyer) (1998, s./p.) e Lauro Cavalcanti (2008, p. 152).

23. Ver Hermano Montenegro (1989). Montenegro trabalhou como diagramador da revista Brasília e integrou a equipe de arquitetos liderada por Oscar Niemeyer na nova capital. 
24. Durante as pesquisas, procurou-se entrevistar Oscar Niemeyer a respeito de sua relação de trabalho com Marcel Gautherot, mas infelizmente o encontro não foi possível. Procuramos também dados junto à Fundação Oscar Niemeyer, que informou não possuir registros sobre o assunto.

25. Cf. Fundação Oscar Niemeyer (1998, s./p.).

26. Como veremos adiante, essa característica é bastante comum nos diversos desenhos de Niemeyer publicados na revista Módulo. sobre o registro das obras -, mas não é possível determinar com precisão como esses diálogos se davam²4.

Uma pequena publicação editada pela Fundação Oscar Niemeyer, Praça dos Três Poderes, de 1998, dá algumas pistas sobre como pode ter sido a relação entre $\circ$ arquiteto e o fotógrafo. $\bigcirc$ livro presta homenagem a Marcel Gautherot, que "acompanhou atentamente os trabalhos de Oscar Niemeyer desde as obras da Pampulha, em 1940" e de quem são "a maioria das fotografias escolhidas pelo arquiteto para retratar sua obra"25. Fotografias da praça são reproduzidas ao lado de croquis de Niemeyer, que costumava pontuar as perspectivas adequadas para a visualização de seus projetos com o desenho de um olho, um monóculo, tal qual uma câmara fotográfica ${ }^{26}$ (Figura 1).

O exemplo chama a atenção pela semelhança entre o enquadramento da fotografia à direita e o último desenho no canto esquerdo da página. Ainda que as imagens mostrem pontos de vistas contrários (uma mira a praça e a outra vê o Supremo Tribunal Federal a partir da praça), ambas destacam a laje do chão, o teto, a sequência de colunas e a lateral do edifício formado por uma caixa de vidro. A escala das pessoas representadas nas duas imagens é praticamente a mesma. Além disso, a foło de Gautherot mostra a praça dos Três Poderes vista por meio do vão livre da fachada do Supremo e pelos espaços vazios entre as colunas, valorizando o perfil das mesmas em sequência, como indicam os croquis do arquiteto. Não é possível afirmar que a foto foi realizada a partir do desenho, mas sim que o trabalho de Gautherot corresponde ao conceito, ou seja, à intenção do projeto proposto por Niemeyer.

As imagens abaixo exemplificam o destaque dado às obras de Niemeyer em Brasília, fotografadas por Gautherot, em revistas internacionais (Figuras 2 a 6). Nessas publicações, a autoria das imagens é quase sempre identificada.
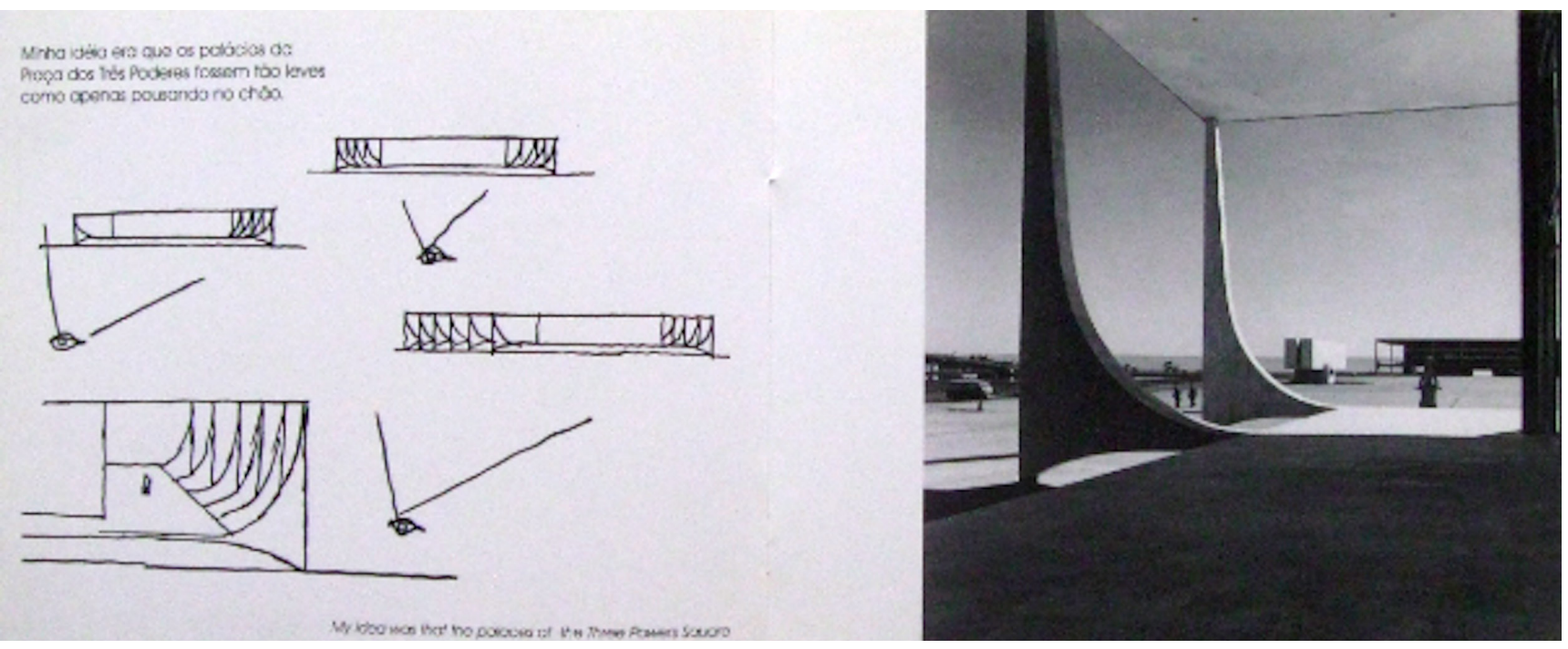

Figura 1 - À esquerda, desenhos do Supremo Tribunal Federal, por Oscar Niemeyer; à direita, fotografia de Marcel Gautherot. Fonte: FUNDAÇÃO OSCAR NIEMEYER. Praça dos Três Poderes. Brasília: Fundação Oscar Niemeyer, 1998. 


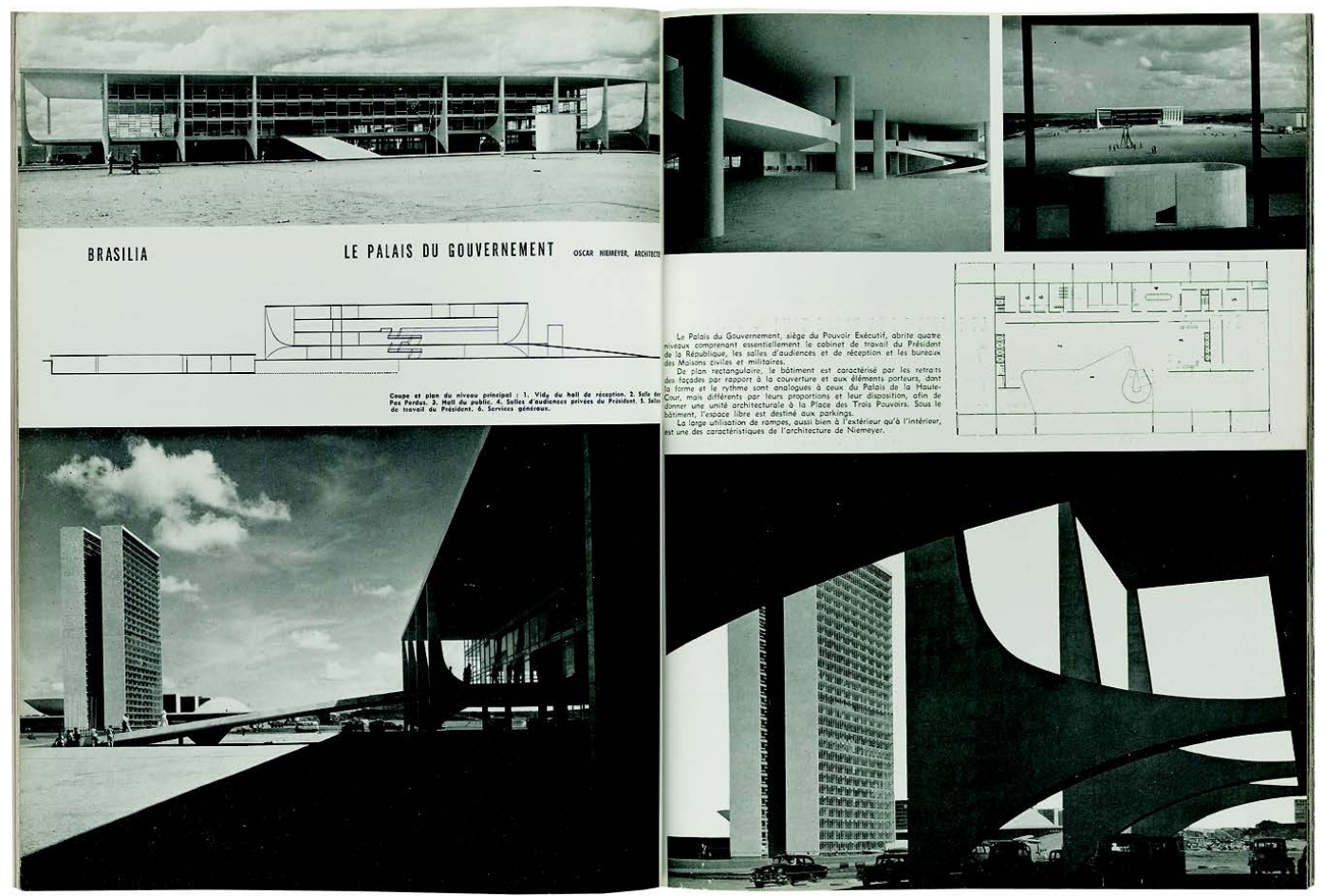

Figura 2 - Fotografias de Marcel Gautherot na revista L'Architecture d'Aujourd'hui - Brèsil Brasilia Actualités, Paris, v. 31, n. 90, jun.jul. 1960, p. 14-15.
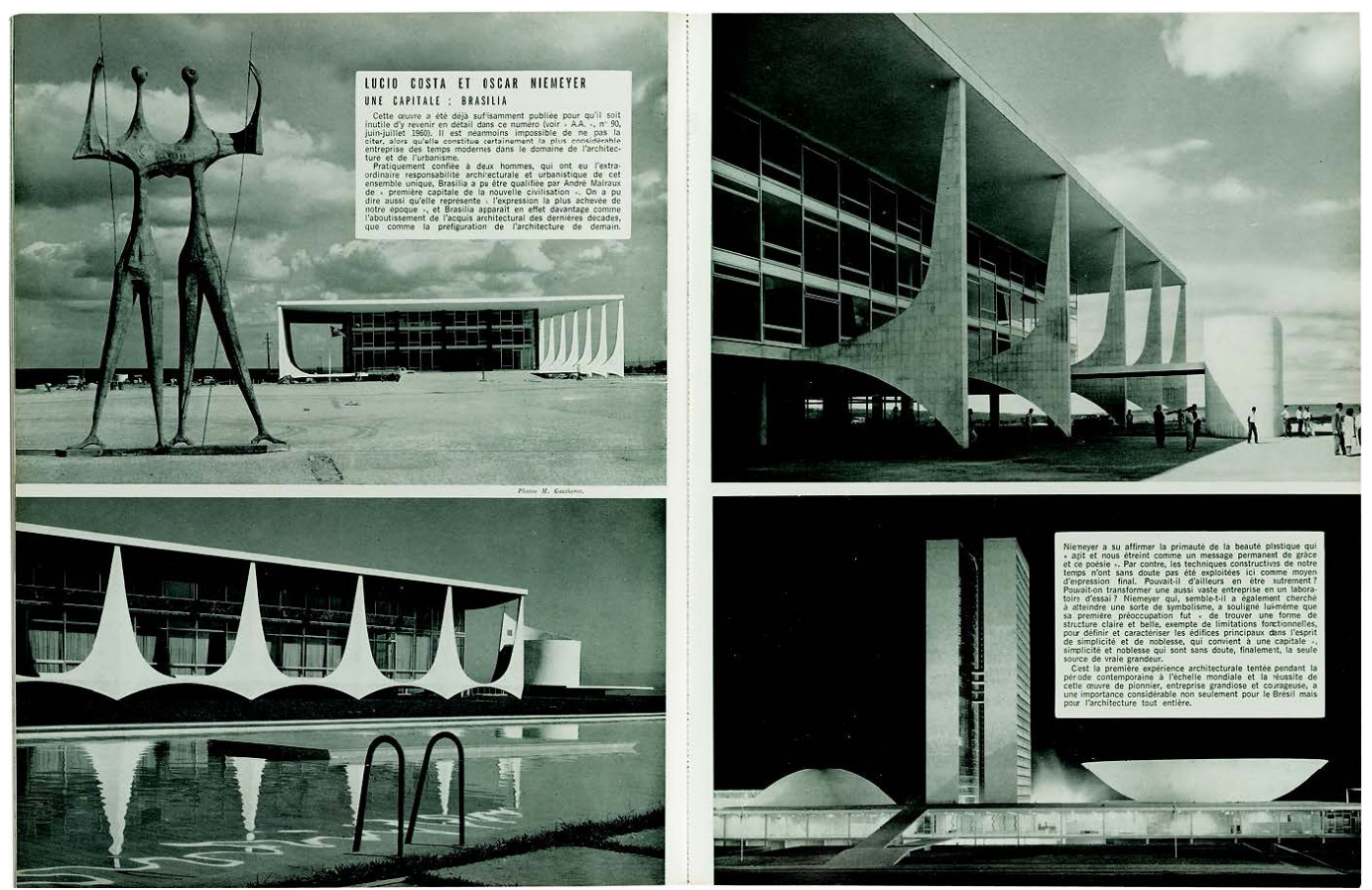

Figura 3 - Fotografias de Marcel Gautherot na revista L'Architecture d'Aujourd'hui - Numero Exceptionnel Panorama 1960, Paris, v. 31 , n. 91 , out.-nov. 1960, p. 14-15.

Annals of Museu Paulista. v. 22. n.1. Jan.-Jun. 2014. 


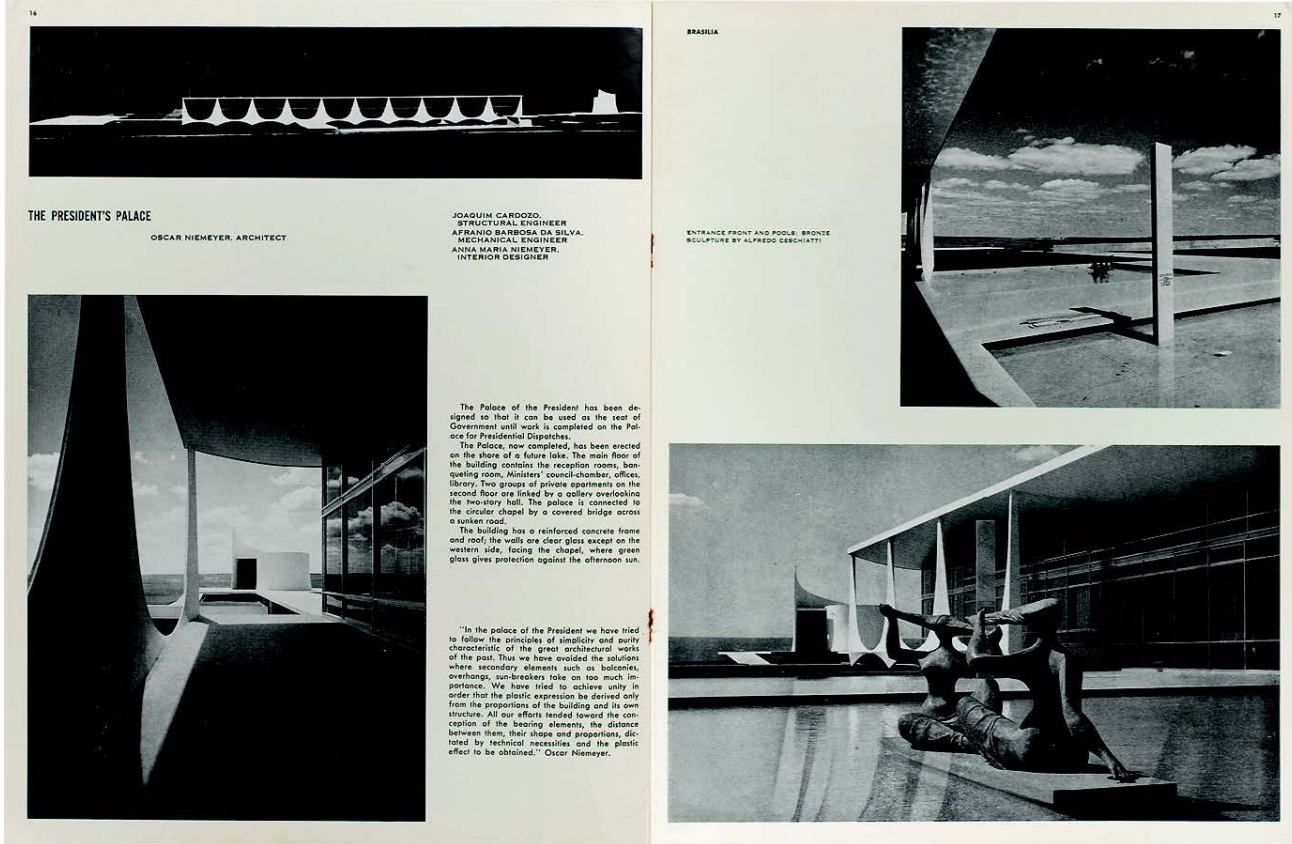

Figura 4 - Fotografias de Marcel Gautherot na revista Arts \& Architecture, Los Angeles, v. 74, n. 4, abr. 1959, p. 16-17.
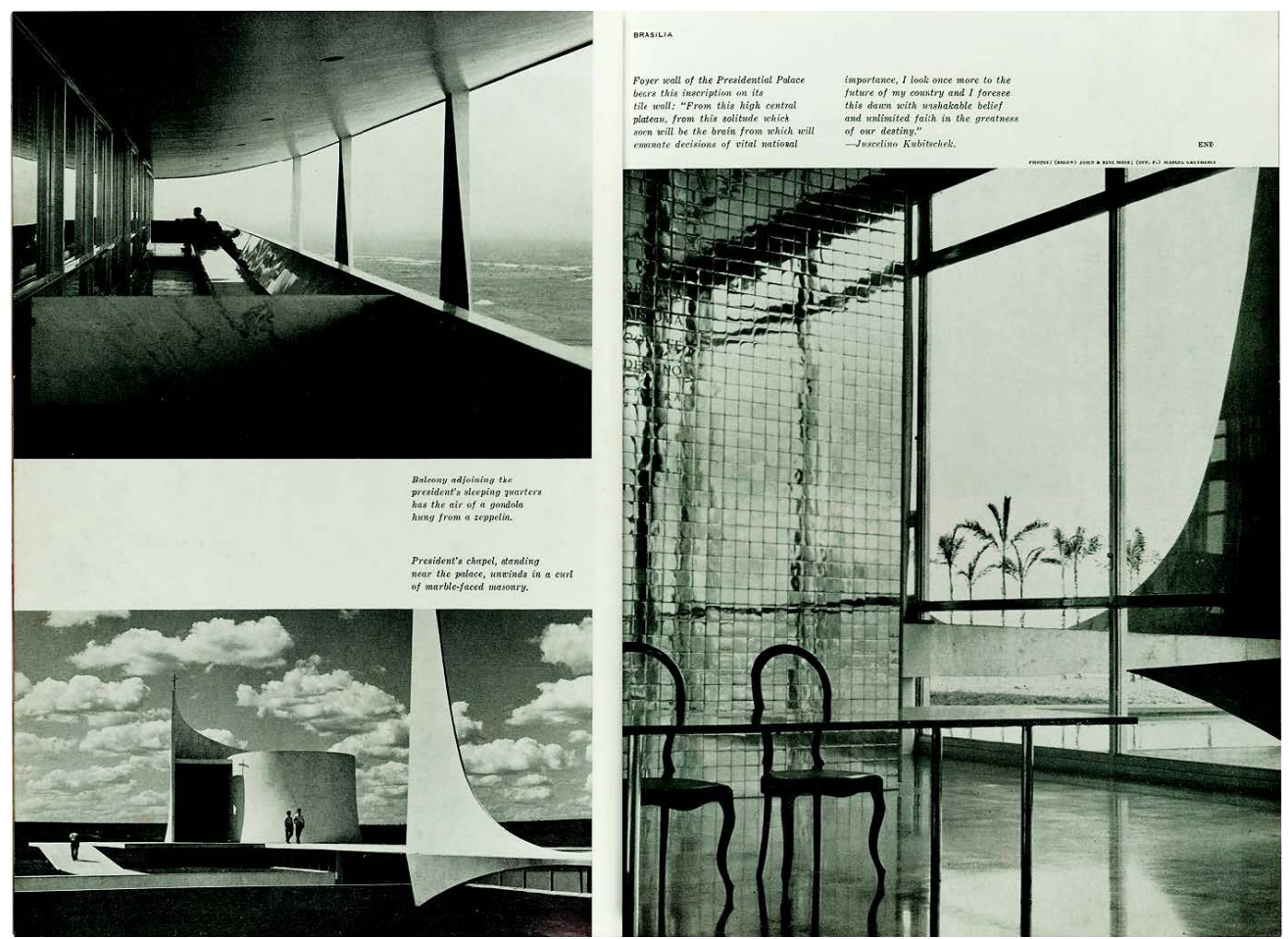

Figura 5 - Fotografias de Marcel Gautherot [reportagem sobre o palácio da Alvorada] na revista The Architectural Forum, Boston, v. 110 , n. 4, abr. 1959. 

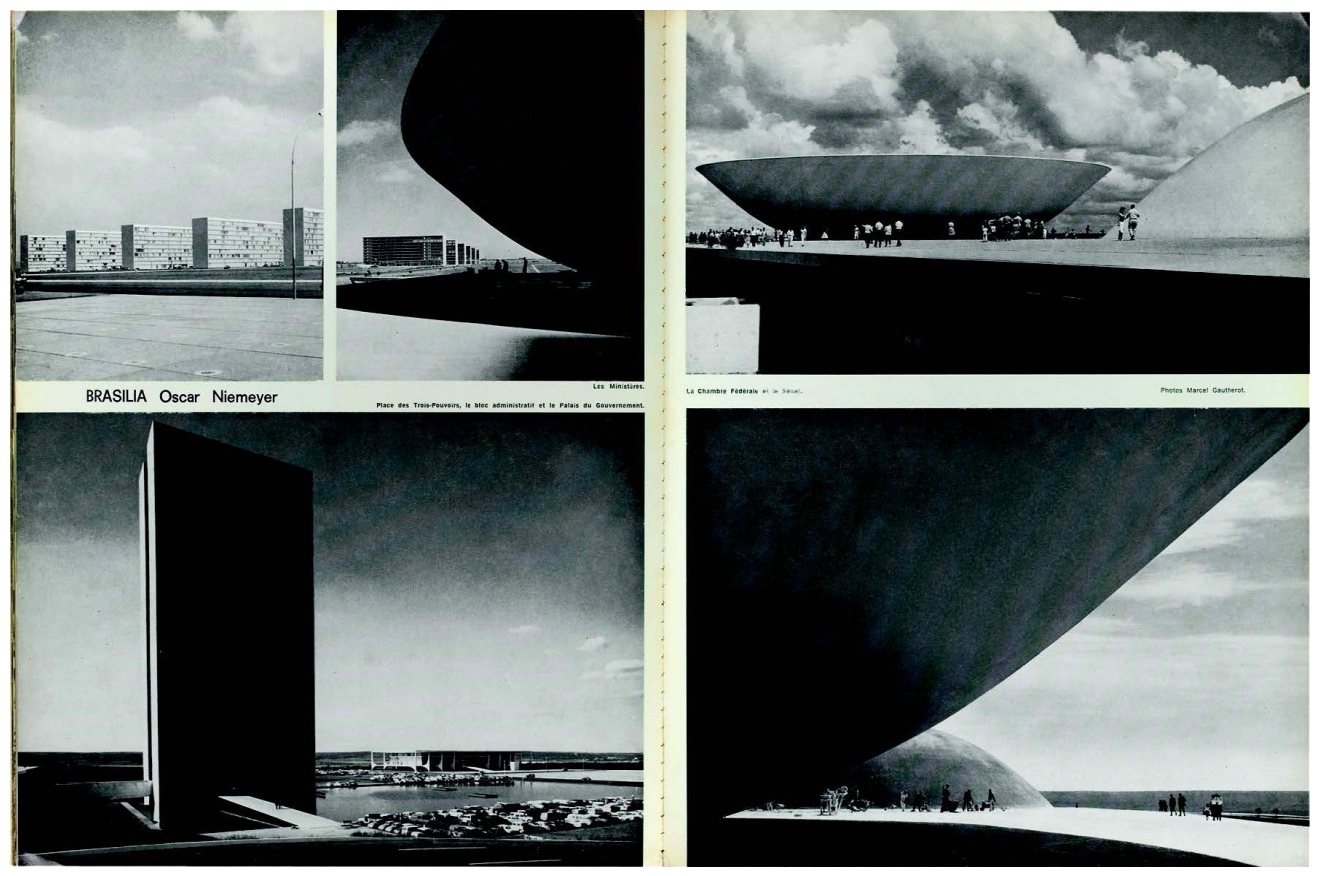

Figura 6 - Fotografias de Marcel Gautherot na revista Aujourd'hui Art et Architecture, Paris, v. 8, n. 46, jul. 1964, p. 36-37.

Módulo: Revista de Arquitetura e Artes Plásticas (1955 - 1964)

A Módulo: Revista de Arquitetura e Artes Plásticas merece destaque tanto pela constância com que publicou as fotos de Gautherot, sendo muitas delas sobre Brasília. Trata-se de uma revista de arquitetura voltada também para questões gerais da cultura e da arte brasileira. Sua proposta é apresentar a arquitetura moderna feita no país, e sobretudo aquela projetada por Oscar Niemeyer, em diálogo com traços marcantes da cultura nacional.

A referência às artes plásticas no título da revista não implicou somente na divulgação de obras e eventos relacionados a essa área, diz respeito também ao argumento de que a arquitetura é uma arte plástica. A ideia é colocada desde a Módulo n 1, em artigo de Niemeyer sobre Le Corbusier, no qual o arquiteto brasileiro afirma que, para o mestre franco-suíço: "Artes plásticas, arquitetura, técnicas de construção e poesia foram sempre para ele assuntos de igual importância, intimamente ligados e impossíveis de isolar" ${ }^{\prime 27}$. Ao longo dos primeiros nove anos da revista ${ }^{28}$, a noção de arquitetura como arte é elaborada em textos de Oscar Niemeyer, Lucio Costa e Joaquim Cardozo ${ }^{29}$ e, como veremos, reforçada por seu projeto gráfico.

A fotografia participa da Módulo como um documento de grande apelo estético e, como tal, recebe amplo destaque. Mesmo assim, são raros os momentos em que as imagens são creditadas, sendo importante frisar que Marcel Gautherot protagoniza a maior parte das situações em que o fotógrafo é creditado, o que sinaliza uma certa ascendência e prestígio. Entre os números 1 (março 1955) e 27
27. Cf. Oscar Niemeyer (1955a, p. 3).

28. A revista existiu, num primeiro momento, entre 1955 e 1964, ano em que sua sede foi invadida por militares, sendo forçada a cessar as atividades. Voltou a ser publicada entre $1975 \mathrm{e}$ 1989. Este texto diz respeito a sua primeira fase.

29. Ver Lucio Costa (1955, p. $17-24 ; 1959$, p. 26-31) e Oscar Niemeyer (1955b, p. 1922 ; 1958 , p. 3-6; 1960, p. 2-7). 
30. A Módulo $\mathrm{n}^{\circ} 28$, de junho de 1962, deixa de citar os nomes dos fotógrafos colaboradores em seu expediente. A partir dessa data, também não foram mais identificadas imagens de Gautherot, que provavelmente deixou de colaborar com a revista.

31. Cf. Juscelino Kubitschek (1956, p. 7).

32. Ver Sophia da Silva Telles (1988, p. 87).

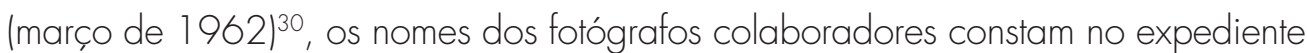
da revista, estando Gautherot citado em todas as edições. Os demais profissionais mencionados são Jean Manzon, José e Humberto Francheschi, Kasmer, Rafael Landau, Foło Carlos, Carlos Botelho, Flávio Damm e Alberto Garbocci.

Antes que os projetos de Niemeyer para a nova capital começassem a ser apresentados na Módulo, a edição no 4 publicou uma entrevista com Juscelino Kubistchek, na qual o presidente verbaliza sem meias-palavras suas expectativas em relação ao papel da arquitetura moderna na políitica do nacional-desenvolvimentismo:

Desde cedo compreendi que a arquitetura moderna era para o Brasil mais do que uma tendência estética, e sobretudo mais do que a projeção de um movimento universal no seio de nossa cultura. (...) Ela se projeta como vigorosa força de afirmação cultural, talvez a que mais se tenha adiantado em originalidade e precisão, entre as manifestações da inteligência criadora dos brasileiros de nossa época.

(...) A futura capital será, no meu entender, a grande realização coletiva da arquitetura, da técnica e das artes plásticas brasileiras, que dará testemunho do espírito e da capacidade da presente geração de técnicos e de $\operatorname{artistas}^{31}$.

Entre dezembro de 1956 (edição nº 6) e dezembro de 1958 (edição nº 11 1) os principais projetos de Niemeyer para Brasília foram capa e tema de todas as edições do periódico. A única exceção é a Módulo n 8, uma tiragem especial sobre o plano piloto, em que foram divulgados o edital do concurso e os projetos finalistas, com destaque para o vencedor. Nesse primeiro momento, as obras de Niemeyer são divulgadas por meio de fotos de maquetes, desenhos técnicos e, com grande destaque, desenhos traçados à mão livre pelo arquiteto, um recurso gráfico que aproxima a revista do leitor não especializado, além de reforçar o sentido "expressivo" dos projetos. Os desenhos ora explicitam as idas e vindas do arquiteto, revelando imprecisões, ora denotam o sentido de economia e clareza de uma linha fina e sinuosa que, como notou Sophia Telles, parece derivar do próprio horizonte ${ }^{32}$. De todo modo, está claro que, na Módulo, o destaque dado ao desenho de Niemeyer direciona a interpretação da arquitetura como uma expressão artística subjetiva.

No segundo semestre de 1958, quando as primeiras edificações da capital começaram a ficar prontas (o Palácio da Alvorada e o Brasília Palace Hotel) e as obras dos eixos monumental e residencial estavam a todo vapor, surgiram as primeiras fotos de Braślia na revisła. Gautherot inicia sua contribuição na Módulo nº 12, lançada em fevereiro de 1959, em duas reportagens sobre os interiores do Palácio da Alvorada e o Brasília Palace Hotel, com grande destaque para as suas imagens que foram editadas, porém, sem os créditos do fotógrafo.

A capa da Módulo no 13 (Figura 7), com foto de Marcel Gautherot e layout de Arthur Licio Pontual, é uma das soluções gráficas mais interessantes da revista e um bom exemplo de como a fotografia era trabalhada com liberdade por seus designers. Pontual, que colaborava com a Módulo desde fevereiro de 1957, reforçou a semelhança com a pintura construtiva desta que talvez seja a imagem de sentido mais abstracionista produzida por Gautherot em Brasília, aproximando seu 
corte e aplicando sobre ela camadas de cor. Os retângulos azuis, verdes e, sobretudo, os vermelhos pintados nos espaços em branco criados pelo alto contraste da imagem original se impõem como formas planas que contrariam a perspectiva desenhada pela sequência de estruturas de ferro dos edifícios dos ministérios, tal como registrada pelo fotógrafo. Ambas as imagens remetem à tese de Max Bill de que o aspecto visual das edificações técnicas foi um dos impulsos fundamentais da arte construtiva ${ }^{33}$. Especialmente a capa faz referência à obra de Mondrian, apesar do efeito da perspectiva não ser completamente eliminado. A peça gráfica sintetiza com clareza o objetivo da revista de mostrar arte e arquitetura como um amálgama indissociável, um argumento que, sob o auxílio precioso do design aliado à fotografia, identifica sobretudo as obras de Brasília. Vale ainda notar que tanto o nome do fotógrafo quando do artista gráfico são identificados no expediente da revista como autores do trabalho.

arquiteto e designer Arthur Licio Pontual colaborou com a Módulo a partir de fevereiro de 1957, tornando-se em seguida funcionário da Novacap, para a qual desenvolveu o projeto e a montagem de uma exposição itinerante sobre Brasília inaugurada no edifício do Ministério da Educação, em 1958, e remontada nesse mesmo ano em diversos países. Entre os anos 1950 e 1960, Pontual se notabilizou como designer gráfico e de exposições de arquitetura, tendo realizado

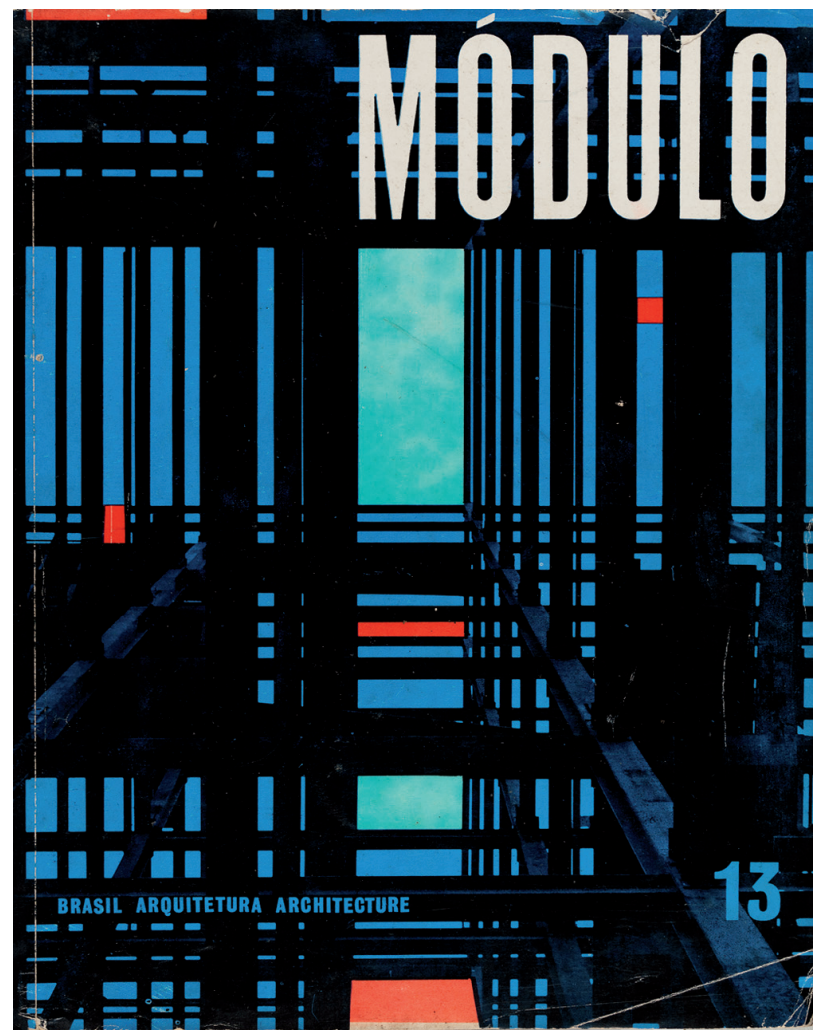

Figura 7 - Capa da Módulo: Revista de Arquitetura e Artes Plásticas, Rio de Janeiro, n. 13, abr. 1959. Projeto gráfico de Arthur Licio Pontual a partir de fotografia de Marcel Gautherot.
33. Ver Max Bill (1977). Publicado originalmente na revista argentina Ver $y$ Estimar, de 1950, nesse texto Max Bill identifica três origens para o construtivismo: 1. as descobertas da matemática moderna; 2 . as sugestões formais das edificações técnicas; 3. a visualidade bidimensional revelada pelas primeiras fotografias aéreas. 
34. Ver Ana Luisa Nobre (2008, p. 80).

35. Ver Oscar Niemeyer (1959, p. 7). alguns projetos com a participação de Marcel Gautherot, como veremos em seguida. Junto com Aloísio Magalhães e Luiz Fernando Noronha, fundou e dirigiu o escritório Magalhães+Noronha+Pontual (M+N+P) no Rio de Janeiro, entre 1960 e 1962 que, como informa Ana Luiza Nobre, tinha o objetivo de realizar projetos de artes gráficas, industriais e arquitetura como um todo, sem hierarquias entre essas áreas ${ }^{34}$.

Na Módulo n 14, fotos de Gautherot ilustram o texto "Brasília vista por um inglês", de J. M. Richards, no qual o autor afirma que nenhum empreendimento arquitetônico de tal tamanho e complexidade é realizado na Inglaterra. Em seguida, aponta preocupações quanto ao desenvolvimento futuro da cidade, mas sem deixar de tecer elogios ao plano piloto e à beleza do Palácio da Alvorada.

A Módulo n 15, com projeto gráfico de Arthur Licio Pontual e Gustavo Goebel Weyne, é uma das edições que mais destacou as fotos de Gautherot de Brasília, especialmente aquelas da construção. Na capa, as manchas gráficas coloridas favorecem a unidade da composição envolvendo fotos de Gautherot, retângulos e um desenho de Niemeyer. Os designers criam uma composição geométrica sugerindo que as fotos e o desenho são parte de uma mesmo retângulo cindido pela linha branca do fundo da página (Figura 8).

A primeira matéria da edição é um longo poema de Joaquim Cardozo intitulado "Arquitetura nascente", dedicado a Oscar Niemeyer, Manuel Bandeira, João Cabral de Melo Neto e Thiago de Mello, e ilustrado com fotos da construção de Brasília feitas por Gautherot. Seu nome é publicado junto às imagens.

$\mathrm{Na}$ foto à esquerda do poema, as estruturas de ferro dos prédios ministeriais em construção parecem suspensas no ar, como se surgissem espontaneamente, de modo que o trabalho dos operários, vistos de longe, parece leve. Em outra dupla de páginas, nas imagens à direita do poema, os candangos aparecem envolvidos na trama gráfica das ferragens, um dado do trabalho de Gautherot que é reforçado pelos designers no recorte retangular de duas fotos, tendo como resultado composições quase totalmente abstratas. As fotos e o quadrado marrom claro na parte superior à esquerda, no qual o nome de Gautheroł aparece em destaque, funcionam na página como os sólidos de uma composição geométrica. Em seu conteúdo e aparência, a matéria sugere que toda atividade envolvendo a edificação de Brasília - a engenharia, a arquitetura, o trabalho no canteiro de obras, os materiais nele utilizados e a fotografia - possui um sentido poético e artístico.

A edição no 15 também publica fotos de Gautherot junto ao texto "A imaginação na arquitetura" e a desenhos de Oscar Niemeyer. No exemplo (Figura 9), nota-se mais uma vez que a escala das pessoas na fotografia de Gautherot segue a proporção que caracteriza os desenhos do arquiteto.

Em seu texto, Niemeyer afirma que o principal recurso de um arquiteto na elaboração de um projeto é sua própria imaginação, sendo ela capaz de prever detalhes, sensações e espaços que maquetes e desenhos não podem sugerir ${ }^{35}$. Como em outros momentos, revestidos de uma bela solução gráfica, o texto, o layout e a fotografia contribuem para criar uma imagem romântica do trabalho em arquitetura. 


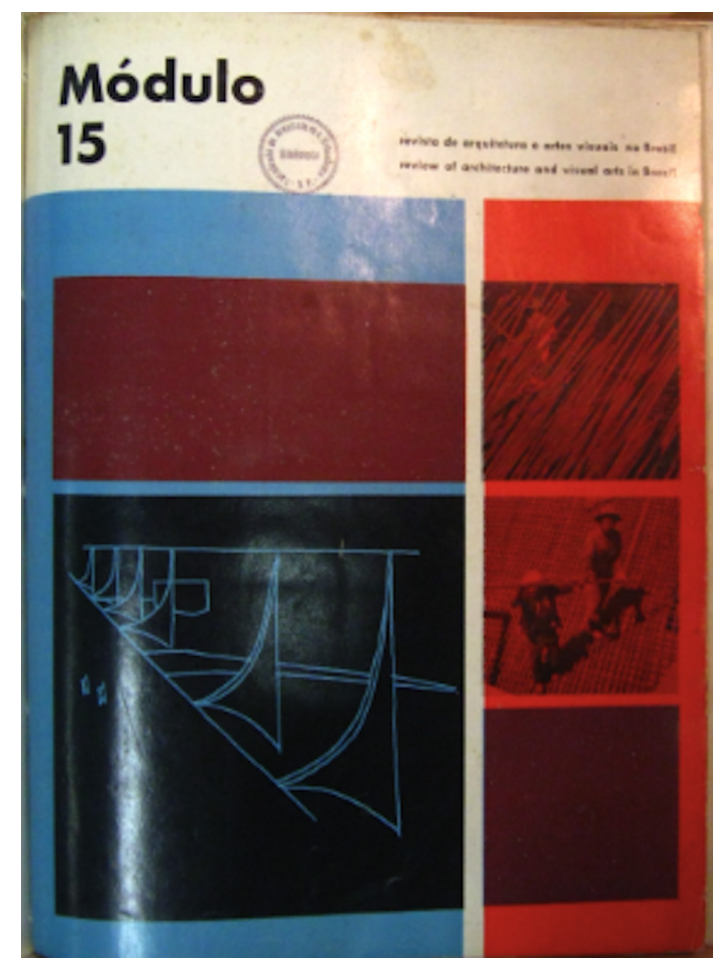

Figura 8 - Módulo: Revista de Arquitetura e Artes Plásticas, Rio de Janeiro, n. 15, out. 1959. Capa de Arthur Licio Pontual e Goebel Weyne; desenho de Oscar Niemeyer; fotografias de Marcel Gautherot.
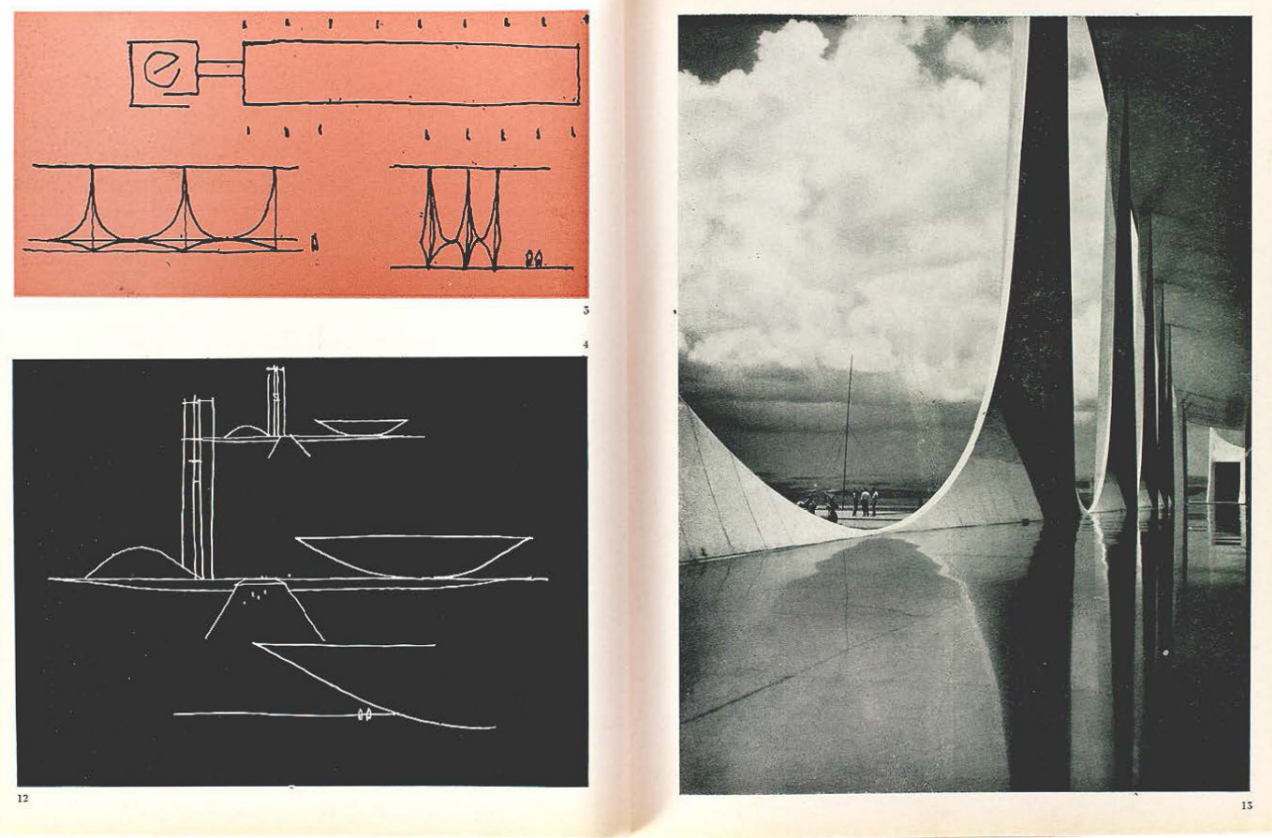

Figura 9 - Páginas do artigo A imaginação na arquitetura. Módulo: Revista de Arquitetura e Artes Plásticas, Rio de Janeiro, n. 15, out. 1959, p. 12-13. Desenhos de Oscar Niemeyer; fotografia de Marcel Gautherot. 
Na Módulo no 18, imagens de Gautherot e de outros colaboradores ilustram o depoimento "Minha experiência em Brasília", de Niemeyer. Em alguns trechos, a narrativa adquire um teor heroico, emotivo, e um tanto idealizador do empreendimento, enfatizando a fraternidade entre técnicos, operários e autoridades. A fotografia de Gautherot que acompanha o texto novamente apresenta um conteúdo predominantemente gráfico e formal, recebendo uma película colorida, o que reforça ainda mais seu caráter plástico.

As fotos do eixo monumental concluído tiveram poucas aparições na Módulo que, como vimos, privilegiou registros do Palácio da Alvorada, do Brasília Palace Hotel e do centro cívico em construção. O período em que Gautherot mais fotografou o setor monumental pronto, o início dos anos 1960, coincide com uma diminuição de sua colaboração direta na revista que, mesmo depois da capital inaugurada, continua divulgando suas imagens da construção. Uma exceção é a edição no 19, que publica uma vista da praça dos Três Poderes ampliada em duas páginas e colorida com uma película vermelha (Figura 10).

Gautherot encerra sua participação na edição especial n 26 dedicada ao engenheiro-poeta Joaquim Cardozo, tendo uma foto sua publicada na capa e várias outras no ensaio gráfico que ao longo da revista acompanha textos de Rodrigo Mello Franco de Andrade, Niemeyer, Jorge Amado, Samuel Rawet e do próprio Cardozo, entre outros.

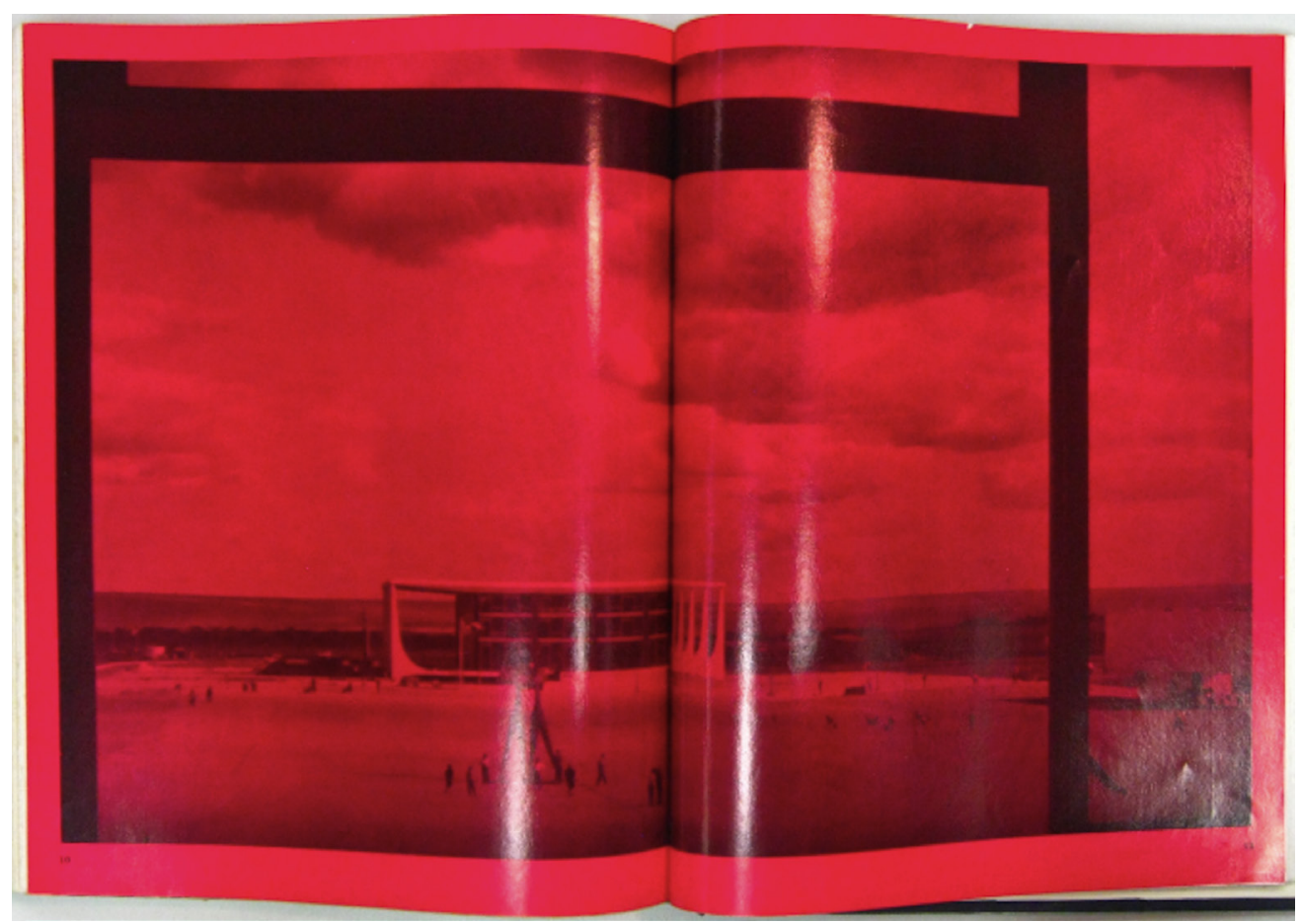

Figura 10 - Módulo: Revista de Arquitetura e Artes Plásticas, Rio de Janeiro, n. 19, ago. 1960, s./p. Fotografia de Marcel Gautherot. 
Gautherot e Brasília nas exposições de arquitetura moderna brasileira ${ }^{36}$

Nos anos 1950 e 1960, o assunto da construção de Brasília integrou ou foi tema de uma série de exposições itinerantes, muitas delas promovidas pela Divisão Cultural do Ministério das Relações Exteriores, tendo os diplomatas Wladimir Murtinho e José Osvaldo Meira Penna como os principais proponentes. Como explica Murtinho, o objetivo das mostras que viajaram pela América Latina, América do Norte, Europa e por países orientais, era construir um discurso histórico que justificasse a construção da nova capital e, sobretudo, afirmar a capacidade do Brasil realizar o empreendimento:

(...) ○ Ministério das Relações Exteriores teve uma influência enorme no lançamento de Brasília, literalmente lançamento. (...) o tema de Brasília, foi algo que teve a maior repercussão, a construção de Brasília, a decisão de fazê-lo, a coragem e o fato de que se tenha feito. Ou seja, havia a mais completa dúvida sobre a capacidade primeiro de fazer, segundo de realizá-lo (...). O Itamaraty julgou que era muito importante usar isto como o tema para a difusão cultural do país. (...).

(...) nós fizemos muitas exposições sobre Brasília na qual mostrávamos lá fora que Brasília tinha uma lógica, uma continuidade. E, essa continuidade, começava com a decisão dos inconfidentes, não? Transferir a capital, mostrávamos que era uma ideia fixa, depois aparece em todas as constituições, ou seja, é uma preocupação verdadeira. Ela é essencialmente o seguinte: se você está nas duas capitais em que nós tivemos, que é Salvador e o Rio de Janeiro, você está virado para fora. (...) A ideia era que nós teríamos, viraríamos para dentro. Isso não aconteceu ainda. Ou seja, é muito difícil você mudar de ideias, (...) reverter todo um equilíbrio. É muito difícil. Mas, eu tenho a impressão, o ltamaraty intuiu isso muito bem. Ou seja, nós fizemos disso a propaganda ${ }^{37}$.

A primeira exposição promovida pelo Ministério das Relações Exteriores sobre a nova capital foi brasilien baut brasilia (brasil constrói brasília), a participação brasileira na Interbau de 1957, mostra de arquitetura realizada anualmente em Berlim. A escultora e artista gráfica Mary Vieira foi encarregada de elaborar o projeto do pavilhão brasileiro que, diante do tema geral proposto pela Interbau, "A cidade do amanhã", anunciou com destaque o slogan: "O Brasil vos diz: a cidade de amanhã é a cidade de hoje". A artista dispôs painéis em três tons de verde com informações e desenhos de Brasília, textos sobre as razões econômicas e políticas que motivaram a transferência da capital, o que incluía fotografias da população indígena do estado de Goiás. Em destaque, no centro do pavilhão, três painéis verticais com fotos de maquetes dos palácios do Congresso, do Planalto e da Alvorada foram encaixados num tablado horizontal de $25 \mathrm{~m}^{2}$ com o desenho do plano piloto. $\bigcirc$ projeto incluía ainda uma bancada apresentando um panorama do desenvolvimento da arquitetura moderna brasileira até Brasília.

Nos anos seguintes, a mostra concebida por Mary Vieira foi mostrada em Viena, Munique, Stuttgart, Zurique e Genebra, tendo sido acrescentados ao projeto original conteúdos sobre o paisagismo de Burle Marx e novos painéis
36. A documentação sobre as feiras e exposições de arquitetura brasileira entre $o$ fim dos anos 1950 e início dos 1960 é bastante escassa. Para a coleta dos dados aqui apresentados foram consultados documentos do Itamaraty em Brasília, do Arquivo Público do Distrito Federal, do Memorial JK, da Casa de Lucio Costa, do Arquivo Noronha Santos, do Arquivo Wanda Svevo/ Fundação Bienal e da Fundação Oscar Niemeyer, além da documentação guardada por Luiz Bernardo Pericás (neto do embaixador Wladimir Murtinho) e de diversas bibliotecas, entre as quais vale citar a do Itamaraty, do Senado e do Congresso Nacional. Ainda assim, a principal fonte de informação sobre o assunto foram matérias em revistas e recortes de jornal nos quais o nome de Gautherot é citado ou nos quais pudemos identificar suas imagens apresentadas em painéis, em registros fotográficos das montagens das exposições.

37. Cf. Wladimir Murtinho (1990, p. 19; 23). 
38. Cf. Ana Luiza Nobre (2001a s./p.). Em pesquisas no arquivo e na biblioteca do Itamaraty, em Brasília, e junto a familiares de Wladimir Murtinho, não foi possível localizar o álbum com fotografias de Gautherot distribuído em embaixadas brasileiras, mencionado neste depoimento pelo embaixador. Murtinho declara ainda a Ana Luiza Nobre (2001a, s./p.) que as fotos do álbum foram "(...) selecionadas do arquivo de Gautherot, entre fotos do Nordeste e de Brasília, principalmente. Eu mesmo fiz essa seleção. Ele apenas nos deu o direito de reprodução, os negativos ficaram com ele. Gautherot era muito organizado e ciumento de seu arquivo".

39. Ver Paul Meurs (2000).

40. Ver Instituto Moreira Salles (2001, p. 114).

41. Ver Anônimo (1958). fotográficos sobre Brasília, material este que foi mostrado também em Milão, em fevereiro de 1958.

Marcel Gautherot participou de algumas dessas exposições com fotos de Brasília, da arquitetura brasileira moderna e colonial e, como veremos, de outros aspectos da cultura nacional. Em depoimento à pesquisadora Ana Luiza Nobre, Wladimir Murtinho ressalta a importância da colaboração de Gautherot nas ações do Itamaraty:

Tive contato com Marcel Gautherot no final dos anos 50, no Ministério das Relações Exteriores. Em 1959-60 adquirimos dele um grande número de clichês, que foram enviados para embaixadas do Brasil em todo o mundo. Creio que eram 100-120 imagens, todas selecionadas do seu arquivo. Antes, em 1958, já havíamos utilizado suas fotos no Pavilhão do Brasil na Exposição Internacional de Bruxelas, cujo projeto era de Sérgio Bernardes. Estas fołos compunham grandes painéis de $18 \times 6 \mathrm{~m}$. Era algo gigantesco, muito impressionante. $(\ldots)$

(...) $\bigcirc$ Ministério das Relações Exteriores sempre teve o maior interesse pelo trabalho de Gautherot. Ele nos ajudou muito a representar o Brasil no exterior ${ }^{38}$.

Em 1958, o pavilhão brasileiro na Exposição Internacional de Bruxelas, com projeto de Sérgio Bernardes, foi organizado em torno do tema "O Brasil constrói uma civilização ocidental nos trópicos" ${ }^{\prime \prime}$, cujo foco era mostrar as riquezas naturais e econômicas do país. $\bigcirc$ evento exibiu imagens e informações sobre a paisagem natural e urbana; a fauna e flora; a diversidade cultural e étnica; diferentes setores da indústria; bens de consumo para exportação; vistas das principais metrópoles; artes visuais e arquitetura, com grande destaque para os projetos de Brasília, o ícone maior do desenvolvimento alcançado pelo país. Um jardim projetado por Burle Marx ocupava o centro do pavilhão. Para tanto, além do Itamaraty, estiveram envolvidos na realização do evento o Ministério da Educação e Cultura, especialmente o DPHAN, o Ministério da Saúde, o Estado Maior das Forças Armadas, Instituto Brasileiro de Geografia e Estatística, Conselho Nacional de Pesquisas, o Museu de Arte Moderna do Rio de Janeiro e o de São Paulo, o Serviço Nacional do Teatro, o Instituto Nacional de Cinema Educativo e o Instituto dos Arquitetos do Brasil.

Grandes painéis fotográficos foram um dos principais e mais impactantes elementos do projeto expográfico desenvolvido por João Maria dos Santos, com a colaboração de Eduardo Anahory, Jack van de Beuque e Artur Licio Pontual. Sabese que Marcel Gautherot participou do evento ${ }^{40}$, no entanto, nos registros fotográficos encontrados sobre o interior do pavilhão, não foi possível identificar se ele colaborou com imagens de Brasília.

Em janeiro de 1958, foi inaugurada a Exposição Permanente de Brasília no edifício do Ministério da Educação e Cultura, no Rio de Janeiro, com projeto de Arthur Licio Pontual. A mostra era composta por gráficos, maquetes, desenhos e painéis fotográficos projetados para serem constantemente renovados de acordo com o andamento das obras na nova capital ${ }^{41}$. Há também notícias de uma mostra 
sobre Brasília organizada pela Divisão Cultural do Itamaraty no edifício da Unesco, em Paris, igualmente projetada por Arthur Licio Pontual; além de uma exposição itinerante sobre arquitetura brasileira, desde o barroco até Brasília, em países da América Latina; e uma mostra menor sobre a nova capital, apresentada em países asiáticos $^{42}$. Não foram encontradas menções sobre a participação de Gautherot nesses eventos.

A Módulo n 15, de outubro de 1959, publicou a notícia da inauguração de uma exposição sobre Brasília no escritório da Panair em Lisboa. Entre os registros que ilustram a matéria, foi possível identificar fotografias de Gautherot nos painéis que compunham a exposição (Figura 11).

Em 1962, o Itamaraty organizou e produziu Spotlight on Brazil, uma grande exposição sobre aspectos culturais e econômicos do país, com o objetivo de ampliar as atividades comerciais entre Brasil e Estados Unidos, apresentada em diversas cidades norte-americanas. De escopo extremamente abrangente, a mostra incluía seções sobre arte e arquitetura (do barroco ao contemporâneo); produtos alimentícios; filatelia; joias e pedras preciosas; indústria cultural (cinema e imprensa); música; folclore; turismo; infraestrutura ferroviária, rodoviária e marítima; minério; bancos; borracha etc. Marcel Gautherot participou da mostra com aproximadamente 60 painéis fotográficos sobre arquitetura brasileira ${ }^{43}$.

A Módulo n 32, de março de 1963, noticia o sucesso de outra exposição itinerante sobre arquitetura brasileira, desta vez inaugurada em Bratislava, cidade da então Tchecoslováquia. A mostra havia já sido exibida em Varsóvia e Praga, e seguiria para cidades da Polônia, Áustria, lugoslávia, Romênia, Bulgária e União Soviética. Organizada pelo Departamento Cultural e de Informação do
42. Ver José Osvaldo de Meira Penna (1959).

43. Ver Ruy Pereira Silva (1962). A exposição foi coordenada pelo cônsul Carlos Alberto Leite Barbosa, com o apoio do ministro João Paulo do Rio Branco, chefe do escritório comercial do Brasil em Nova York, e dos diplomatas Wladimir Murtinho e Armando Salgado Mascarenhas.

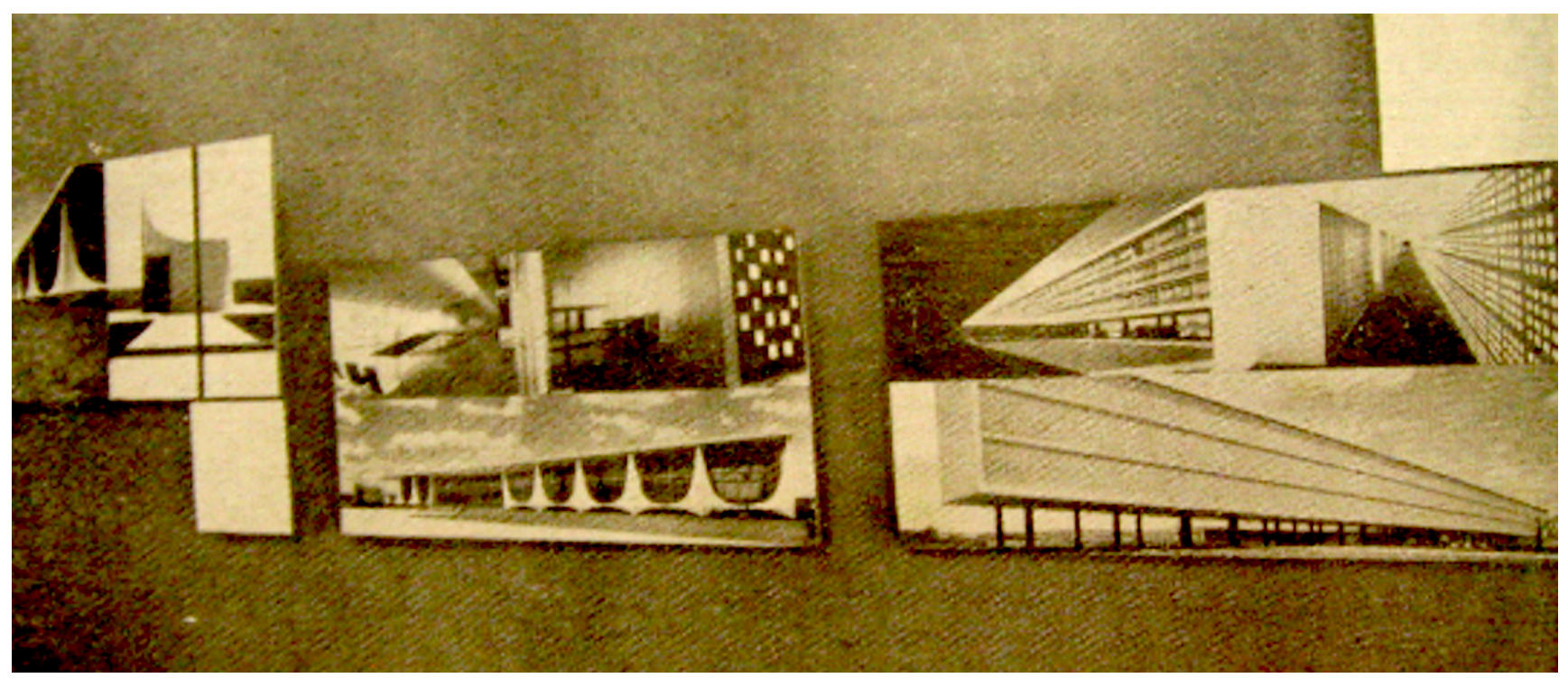

Figura 11 - Painéis com fotografias de Marcel Gautherot na exposição de Brasília em Lisboa, em 1959. À esquerda, interiores e exteriores do palácio da Alvorada e capela; à direita, Brasília Palace Hotel. Fonte: Anônimo. Exposição Brasília em Lisboa. Módulo: Revista de Arquitetura e Artes Plásticas, Rio de Janeiro, n. 15, out. 1959, p. 40. 
44. Ver Anônimo (1963, p. 60-61).

45. Ver Gustavo Lins Ribeiro (2008)
Ministério das Relações Exteriores e projetada pelo escritório Noronha+Magalhães+Pontual, a exposição foi dividida em três seções (barroco, arquitetura contemporânea e Braślia) apresentadas por meio de noventa ampliações fotográficas de $1 \times 1 \mathrm{~m}$, de Marcel Gautherot e Michel Aertsens ${ }^{44}$ (Figura 12).

As qualidades estéticas das fotos de Gautherot em ampliações de grande porte não eram um detalhe menor nesses sofisticados projetos museográticos. Suas imagens tinham o objetivo claro de convencer o visitante sobre a qualidade técnica e artística da arquitetura brasileira. Não sendo a fotografia propriamente dita o assunto de tais exposições, sua função era a de confundir sua própria beleza com a beleza das obras arquitetônicas (ou pessoas, cidades, frutos, danças folclóricas etc.) representadas, sendo como uma janela transparente de acesso a uma realidade distante e idealizada.
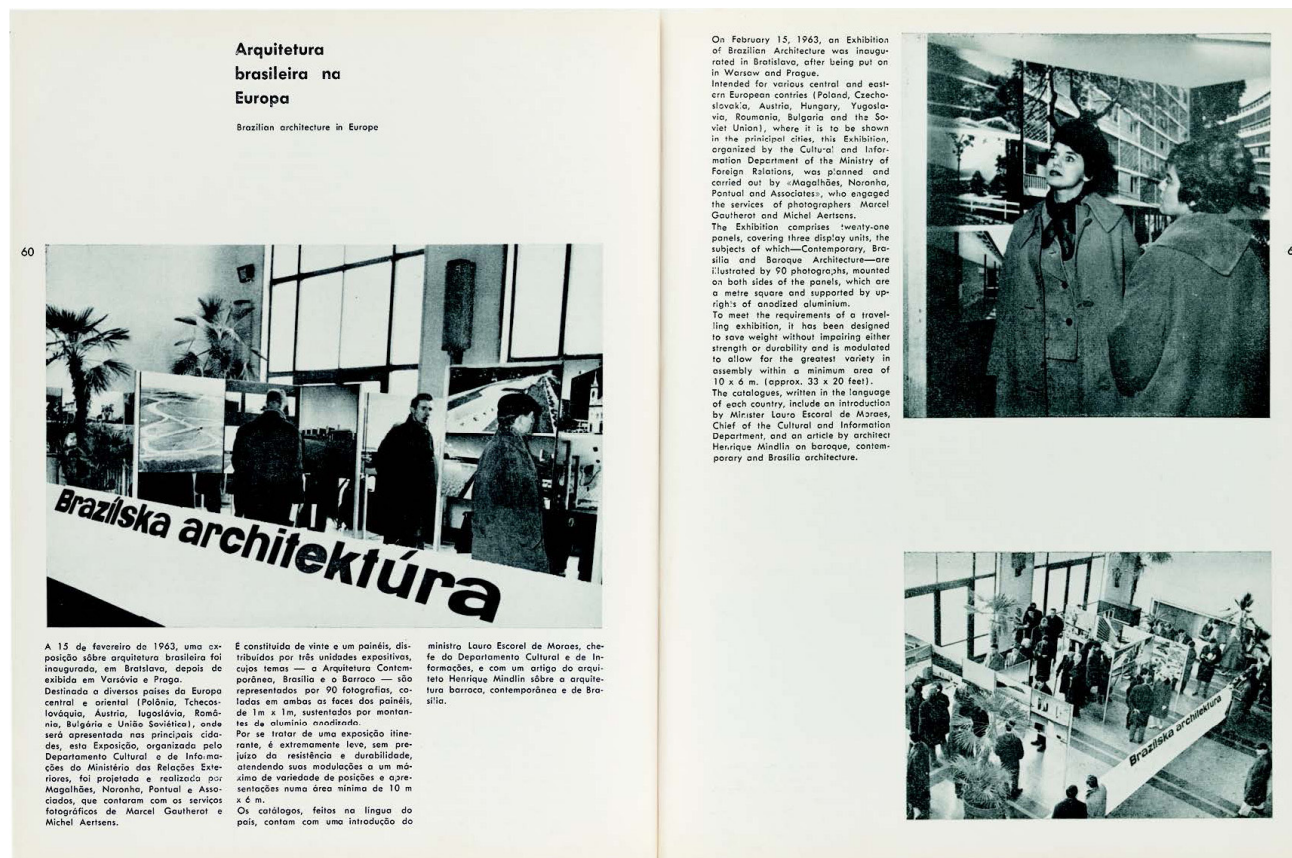

Figura 12 - Páginas do artigo Arquitetura brasileira na Europa. Módulo: Revista de Arquitetura e Artes Plásticas, Rio de Janeiro, n. 32, mar. 1963, p. 60-61. Na página à esquerda, painéis fotográficos com imagens de Brasília, por Marcel Gautherot.

Sacolândia: a Brasília fora de circulação

Desde seu início, e a despeito das propostas do Plano Piloto, Brasília se tornou um microcosmo dos problemas sócio-políticos do país, replicando privilégios, dicotomias, a exploração extremada da força de trabalho, más condições de moradia para os operários e suas famílias. De acordo com Gustavo Lins Ribeiro45, o afluxo de imigrantes se deu tanto de forma espontânea quanto organizada pela iniciativa privada e pública. Principalmente nos primeiros momentos da construção, 
entre o fim de 1956 e início de 1957, quando a área ainda se encontrava isolada, muitos trabalhadores chegaram por conta própria, sozinhos ou com suas famílias, sem emprego garantido, procurando por recrutamento diretamente junto às construtoras. Já o afluxo organizado era realizado por um aliciador de mão de obra, uma empresa particular ou um órgão público, com a tarefa de contratar os operários de acordo com as demandas da obra, sendo responsável por eles desde sua saída do local de origem até seu ingresso na atividade produtiva. Os órgãos de aliciamento oficiais ou não privilegiavam o emprego de homens sem família, jovens e saudáveis, que então eram instalados nos alojamentos da chamada Candangolândia, da Novacap (Companhia Urbanizadora da Nova Capital), ou da Vila Planalto, a área reservada para os acampamentos dos funcionários das construtoras privadas. A partir de 1957, a chegada de todos os trabalhadores passou a ser controlada pelo Inic (Instituto Nacional de Imigração e Colonização), que funcionava junto à Novacap, com a função de registrar, selecionar e inserir os candidatos nos postos ${ }^{46}$.

Sobretudo a partir de 1958, quando uma forte seca no Nordeste estimulou a vinda de milhares de famílias carentes para Brasília, os problemas de moradia no canteiro de obras ficaram evidentes. Sem condições para pagar os altos aluguéis dos alojamentos no Núcleo Bandeirantes, muitas famílias de operários passaram a ocupar áreas irregulares em torno do Plano Piloto. Os assentamentos conhecidos como Sacolândia eram constituídos por barracos feitos com os restos da grande obra: pedaços de madeira e sacos de cimento vazios.

Gautherot não ficou indiferente a essa situação. Paralelamente aos registros das obras oficiais no Plano Piloto, ele realizou um conjunto de aproximadamente 70 fotografias da Sacolândia. Essas imagens demonstram que, apesar de ser comissionado por Niemeyer e pela Novacap, que esperavam uma representação positiva do empreendimento, ele encontrou também espaço para circular em Brasília com liberdade, registrando o que não interessaria ao governo ou às revistas de arquitetura. Num dos seus poucos depoimentos, em 1989, o fotógrafo conta que tinha a intenção de editar um livro sobre a Sacolândia, mas não encontrou editoras interessadas no projeto $^{47}$ (Figuras 13 a 16).

Com enquadramentos frontais e luz dura, as fotos de Gautherot mostram a precariedade e a miséria da Sacolândia com crueza. A intenção é, sobretudo, descritiva e documental. Em algumas delas, as pessoas se confundem com o entorno, camufladas em sombras entrecortadas e densas, em meio à vegetação do cerrado e ao lixo. Noutras, crianças, homens e mulheres posam passivamente diante de suas casas maltrapilhas. Nos anos 1930, Gautherot começou a fotografar enquanto trabalhava como designer de exposições no Museu do Homem, em Paris, junto ao antropólogo Paul Rivet, num ambiente de debate sobre as formas de documentar e expor as culturas não européias, sobre os parâmetros da antropologia e da etnografia modernas. No Brasil desde 1940, o fotógrafo se dedicou a registrar o trabalho, as moradias e festas populares principalmente no Norte e Nordeste do país, a pedido do Serviço do Patrimônio Histórico e Artístico Nacional
46. Ver Gustavo Lins Ribeiro (2008, p. 78-85).

47. Ver Lygia Segala (1989). 


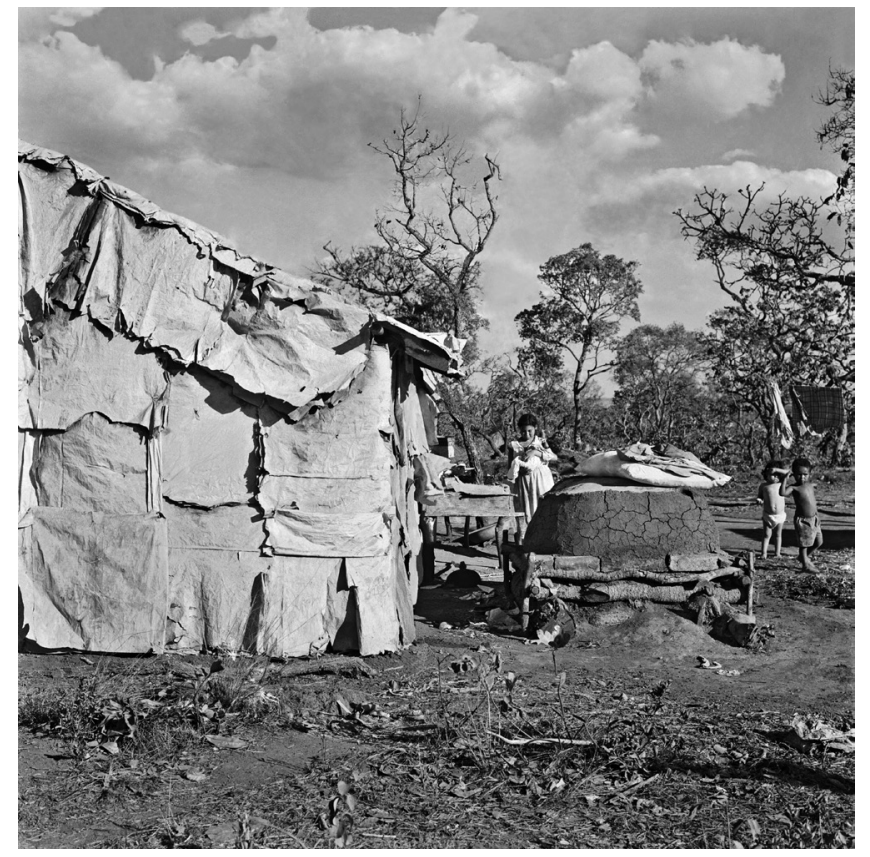

Figura 13 - Marcel Gautherot. Sacolândia, c. 1958. Acervo do Instituto Moreira Salles, Rio de Janeiro.

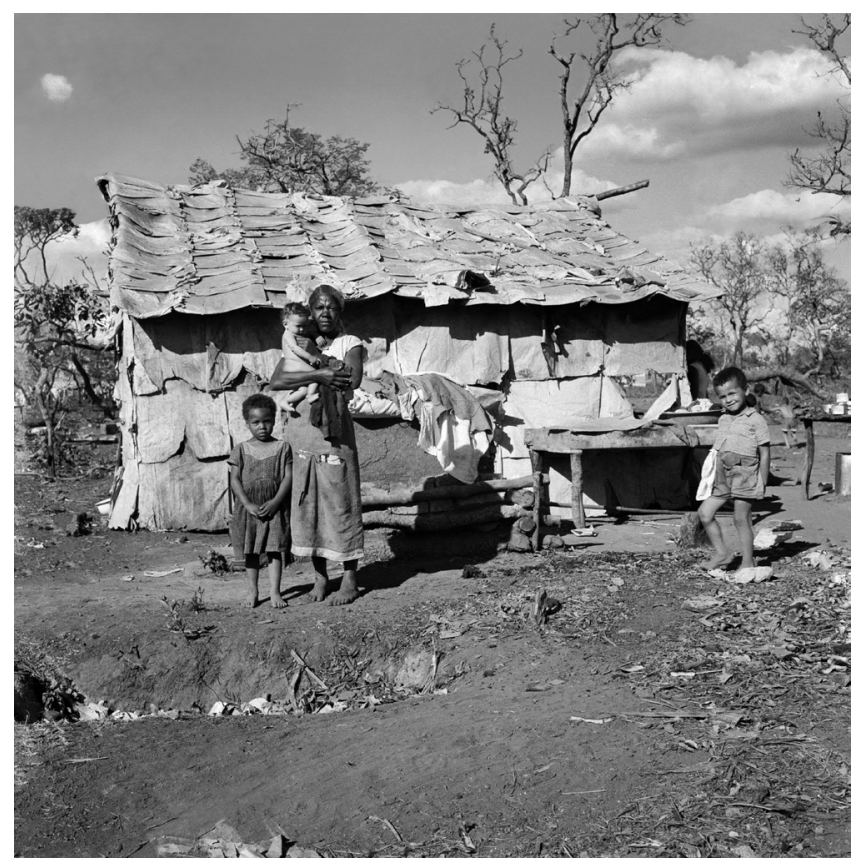

Figura 15 - Marcel Gautherot. Sacolândia, c. 1958. Acervo do Instituto Moreira Salles, Rio de Janeiro.

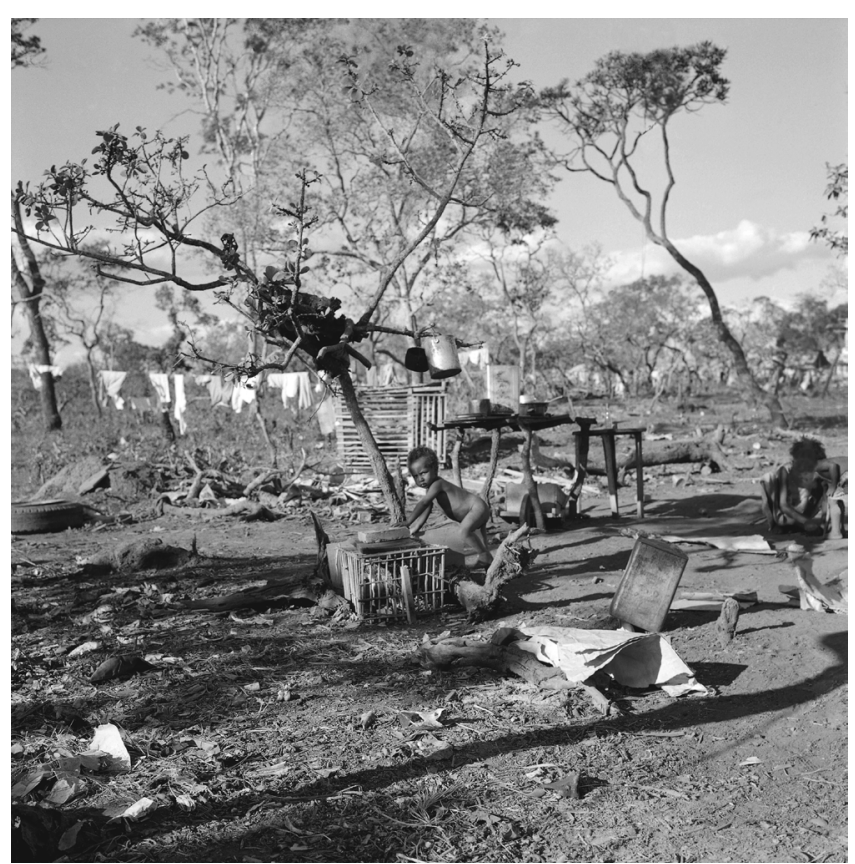

Figura 14 - Marcel Gautherot. Sacolândia, c. 1958. Acervo do Instituto Moreira Salles, Rio de Janeiro.

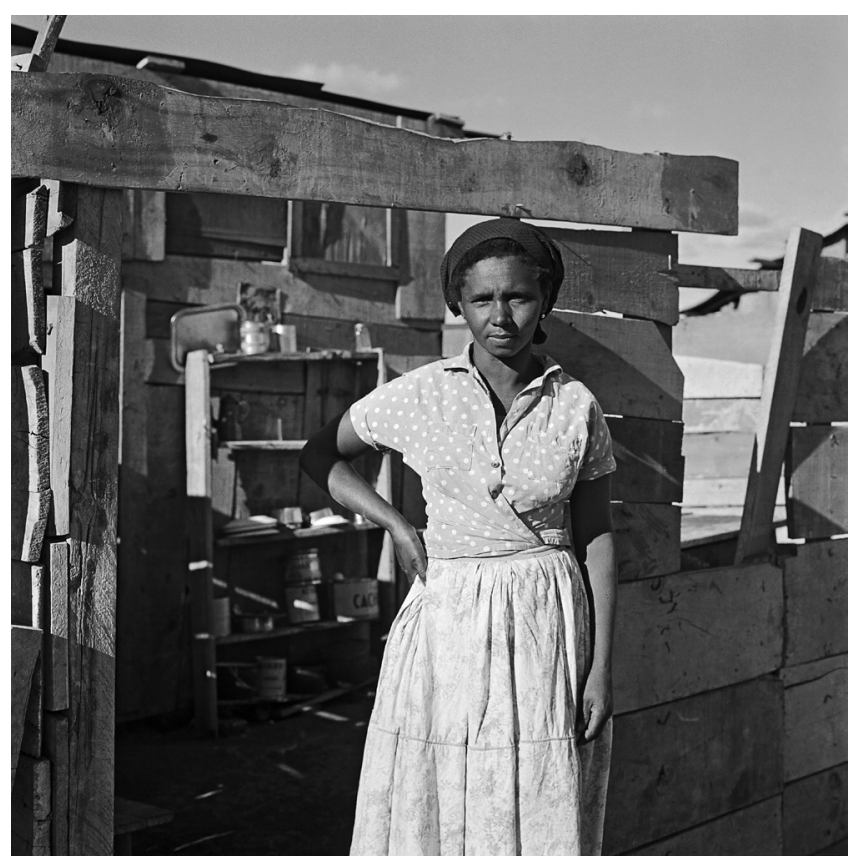

Figura 16 - Marcel Gautherot. Sacolândia, c. 1958. Acervo do Instituto Moreira Salles, Rio de Janeiro. 
(SPHAN), da Comissão Nacional de Folclore ou da Campanha de Defesa do Foldore Brasileiro.

Suas imagens da Sacolândia vieram a público apenas em edições recentes que redimensionaram as leituras sobre a atuação de Gautherot na nova capital $^{48}$. Essa situação, em contraste com a ampla divulgação das fotografias de arquitetura realizadas por Gautherot na mesma época, demonstra que sua coleção de 3.500 fotografias sobre o assunto permanece como um material sujeito a releituras e re-significações. Como aconteceu nos anos 1950 e 1960, no contexto das revistas e exposições aqui analisadas, o significado dessas imagens continua sendo, em parte, direcionado pelas formas de apresentação, pelas intenções editoriais e curatoriais que as envolvem.

\section{REFERÊNCIAS}

ANGOTTI-SALGUEIRO, Heliana (org.). O olbo fotográfico: Marcel Gautherot e seu tempo. São Paulo: Faap, 2007.

ANÔNIMO. Brasília em exposição permanente. Módulo: Revista de Arquitetura e Artes Plásticas, Rio de Janeiro, n. 9, p. 34-37, fev. 1958.

ANÔNIMO. Arquitetura brasileira na Europa. Módulo: Revista de Arquitetura e Artes Plásticas, n. 32, p. 60-61, mar. 1963.

BENJAMIN, Walter. Pequena história da fotografia. In: Magia e técnica, arte e política: ensaios sobre literatura e história da cultura. São Paulo: Brasiliense, 1994.

BILL, Max. O pensamento matemático da arte de nosso tempo. In: AMARAL, Aracy (coord.). Projeto construtivo brasileiro na arte: 1950-1962. Rio de Janeiro: Museu de Arte Moderna do Rio de Janeiro; São Paulo: Pinacoteca do Estado de São Paulo, 1977, p. 50-54.

CAVALCANTI, Lauro. Oscar Niemeyer: trajetória e produção contemporânea. Curitiba: Museu Oscar Niemeyer, 2008.

COSTA, Lucio. A arte e a educação. Módulo: Revista de Arquitetura e Artes Plásticas, Rio de Janeiro, n. 16, p. 26-31, dez. 1959.

O arquiteto e a sociedade contemporânea. Módulo: Revista de Arquitetura e Artes Plásticas, Rio de Janeiro, n. 2, p. 17-24, ago. 1955.

ELWALL, Robert. Building with Light: the International History of Architectural Photography. Londres; Nova York: Merrel Publishers, 2004.

ESPADA, Heloisa (org.). As construções de Brasília. São Paulo: Instituto Moreira Salles, 2010.

FUNDACIÓN JUAN MARCH. Cold America. Geometric abstraction in Latin America (19341973). Madri: Fundación Juan March, 2011.

48. Ver Heliana Angotti-Salgueiro (2007), Heloisa Espada (2010), Samuel Titan Jr. e Sérgio Burgi (2010). 
FUNDAÇÃO OSCAR NIEMEYER. Praça dos Três Poderes. Brasília: Fundação Oscar Niemeyer, 1998.

GAUTHEROT, Marcel et al.. O Brasil de Marcel Gautherot: fotografias. São Paulo: Instituto Moreira Salles, 2001.

GOODWIN, Philip. Brazil Builds: Architecture New and Old 1652-1942. Nova York: MoMA, 1943.

KUBITSCHEK, Juscelino. O presidente e a arquitetura. Módulo: Revista de Arquitetura e Artes Plásticas, Rio de Janeiro, n. 4, p. 7, mar. 1956.

KUDIELKA, Robert et al. Das Verlangen nach Form. Neoconcretismo und zeitgenössische Kunst aus Brasilien. Berlim: Akademie der Künste, 2010.

LOHSE, Richard Paul. Nouvelles conceptions de l'exposition. Zurique: Architektur, 1953.

MEURS, Paul. O pavilhão brasileiro na Expo de Bruxelas, 1958. Arquiteto Sérgio Bernardes. Arquitextos, São Paulo, 01.007, Vitruvius, dez 2000, disponível em <http://www.vitruvius. com.br/revistas/read/arquitextos/01.007/947>, acesso em 04 abr. 2011.

MONTENEGRO, Hermano. Depoimento - Programa de História Oral. Brasília: Arquivo Público do Distrito Federal, 1989.

MURTINHO, Wladimir do Amaral. Depoimento - Programa de História Oral. Brasília: Arquivo Público do Distrito Federal, 1990.

NIEMEYER, Oscar. Convidado pelo Centro de Transmissões Francesas (...). Módulo: Revista de Arquitetura e Artes Plásticas, Rio de Janeiro n. 1, mar. 1955a.

Problemas atuais da arquitetura brasileira. Módulo: Revista de Arquitetura e Artes Plásticas. Rio de Janeiro, n. 3, p. 19-22, dez. 1955b.

Depoimento. Módulo: Revista de Arquitetura e Artes Plásticas, Rio de Janeiro, n. 9, p. 3-6, fev. 1958.

A imaginação na arquitetura. Módulo: Revista de Arquitetura e Artes Plásticas, n. 15, p. 7 , out. 1959 .

. Forma e função na arquitetura. Módulo: Revista de Arquitetura e Artes Plásticas, n. 21, p. 2-7, dez. 1960.

NOBRE, Ana Luiza. Dossiê de pesquisa sobre Marcel Gautherot, 2001a. Datiloscrito. Inédito. Acervo do Instituto Moreira Salles, Rio de Janeiro.

. A eficácia do corte. In: GAUTHEROT, Marcel et al.. O Brasil de Marcel Gautherot: fotografias. São Paulo: Instituto Moreira Salles, 2001b.

. Fios cortantes: projeto e produto, arquitetura e design no Rio de Janeiro (1950-70). Tese (doutorado) - Pós-Graduação em História Social da Cultura / Pontifícia Universidade Católica do Rio de Janeiro, Rio de Janeiro, 2008. 
PAPADAKI, Stamo. The work of Oscar Niemeyer. Nova York: Reinhold, 1950.

PENNA, José Osvaldo de Meira. Exposições de arquitetura brasileira. Módulo: Revista Brasileira de Arquitetura e Artes Plásticas, Rio de Janeiro, n. 13, p. 38-45. abr. 1959.

RIBEIRO, Gustavo Lins. O capital da esperança: a experiência dos trabalhadores na construção de Brasília. Brasília: Editora da Universidade de Brasília, 2008.

SEGALA, Lygia. Entrevista, com Marcel Gautherot. Rio de Janeiro, Museu do Folclore, 07.12.1989. Acervo Instituto Moreira Salles, Rio de Janeiro.

SILVA, Ruy Pereira da. Relatório de Ruy Pereira da Silva sobre trabalhos de seu setor na organização da mostra Spotlight on Brazil. Rio de Janeiro, 11 jan. 1962”.Arquivo do Ministério das Relações Exteriores, Brasília.

TELLES, Sophia da Silva. Arquitetura moderna no Brasil: o desenho da superfície. . Dissertação (Mestrado) - Faculdade de Filosofia, Letras e Ciências Humanas / Universidade de São Paulo, São Paulo, 2008.

TITAN Jr., Samuel; BURGI, Sérgio (org.). A Brasília de Marcel Gautherot. São Paulo: Instituto Moreira Salles, 2010.

Artigo apresentado em 17/08/2012. Aprovado em 09/05/2014. 